\title{
A Novel Convergent Synthesis of the Potent Antiglaucoma Agent Tafluprost
}

\author{
Małgorzata Krupa ${ }^{1}$, Michał Chodyński ${ }^{1}$, Anna Ostaszewska ${ }^{1}$, Piotr Cmoch $^{1,2}$ and \\ Iwona Dams ${ }^{1, *}$ \\ 1 R \& D Chemistry Department, Pharmaceutical Research Institute, Rydygiera 8, 01-793 Warsaw, Poland; \\ m.krupa@ifarm.eu (M.K.); m.chodynski@ifarm.eu (M.C.); a.ostaszewska@ifarm.eu (A.O.); \\ piotr.cmoch@icho.edu.pl (P.C.) \\ 2 Institute of Organic Chemistry, Polish Academy of Sciences, Kasprzaka 42/52, 01-224 Warsaw, Poland \\ * Correspondence: dams@ifarm.eu; Tel.: +48-22-456-3929; Fax: +48-22-456-3838
}

Academic Editor: Derek J. McPhee

Received: 5 December 2016; Accepted: 25 January 2017; Published: 31 January 2017

\begin{abstract}
Tafluprost (AFP-168, 5) is a unique 15-deoxy-15,15-difluoro-16-phenoxy prostaglandin $\mathrm{F}_{2} \alpha$ $\left(\mathrm{PGF}_{2 \alpha}\right)$ analog used as an efficacious ocular hypotensive agent in the treatment of glaucoma and ocular hypertension, as monotherapy, or as adjunctive therapy to $\beta$-blockers. A novel convergent synthesis of 5 was developed employing Julia-Lythgoe olefination of the structurally advanced prostaglandin phenylsulfone 16, also successfully applied for manufacturing of pharmaceutical grade latanoprost (2), travoprost (3) and bimatoprost (4), with an aldehyde $\omega$-chain synthon 17. The use of the same prostaglandin phenylsulfone 16, as a starting material in parallel syntheses of all commercially available antiglaucoma $\mathrm{PGF}_{2 \alpha}$ analogs $\mathbf{2 - 5}$, significantly reduces manufacturing costs resulting from its synthesis on an industrial scale and development of technological documentation. Another key aspect of the route developed is deoxydifluorination of a trans-13,14-en-15-one 30 with Deoxo-Fluor. Subsequent hydrolysis of protecting groups and final esterification of acid 6 yielded tafluprost (5). The main advantages are the preparation of high purity tafluprost (5) and the application of comparatively cheap reagents. The preparation and identification of two other tafluprost acid derivatives, tafluprost methyl ester (32) and tafluprost ethyl amide (33), are also described.
\end{abstract}

Keywords: tafluprost; prostaglandins; Corey lactone; Julia-Lythgoe olefination; fluorination

\section{Introduction}

The discovery of potent and efficacious intraocular pressure (IOP) lowering $\mathrm{PGF}_{2 \alpha}$ analogs 1-5 (Figure 1) has revolutionized the treatment of ocular hypertension, a major risk factor for progression of the irreversible blinding disease glaucoma [1,2]. Until recently, free isopropyl ester prodrugs, i.e., unoprostone (1, Rescula), latanoprost (2, Xalatan) and travoprost (3, Travatan), and one amide prodrug bimatoprost (4, Lumigan) of $\omega$-chain modified $\mathrm{PGF}_{2 \alpha}$ analogs have been used as first line therapy for the treatment of open angle glaucoma and ocular hypertension due to their potent IOP-lowering efficacy, low likelihood of systemic adverse effects, once-daily dosing and good patient adherence [3-6]. However, all the available commercial preparations of 1-4 contain preservatives to maintain the sterility of the solutions, which may impair topical tolerance of these IOP-lowering agents during long-term use [7]. New preservative-free agents with greater IOP-lowering efficacy and milder local side effects are therefore still needed.

Tafluprost (5) is the newest 15-deoxy-15,15-difluorinated $\mathrm{PGF}_{2 \alpha}$ receptor agonist possessing effective IOP-reducing effects, and also the first hypotensive drug released in a preservative-free formulation under trade names Taflotan or Saflutan in Europe and Zioptan in USA [8-12]. 
A preservative-free tafluprost formulation is as potent as a preserved one (BAK-Tapros, Osaka, Japan), but it has fewer and milder toxic effects on the eye. Therefore, it may be particularly beneficial for patients who are sensitive to preservatives, such as patients with dry eyes, and patients who discontinue medication early because of adverse events. Compared with other PGF $2 \alpha$ analogs 2-4, the major modification of tafluprost is the substitution of the C-15 hydrogen and hydroxyl group with two fluorine atoms. Tafluprost is a prodrug containing an isopropyl ester moiety that is rapidly hydrolyzed by corneal esterases to the pharmacologically active metabolite tafluprost free acid (AFP-172, 6) [13]. Tafluprost acid has 12 times the affinity for the prostaglandin F receptor as does latanoprost acid, while having almost no affinity for related receptors, such as prostaglandin D or E [14].
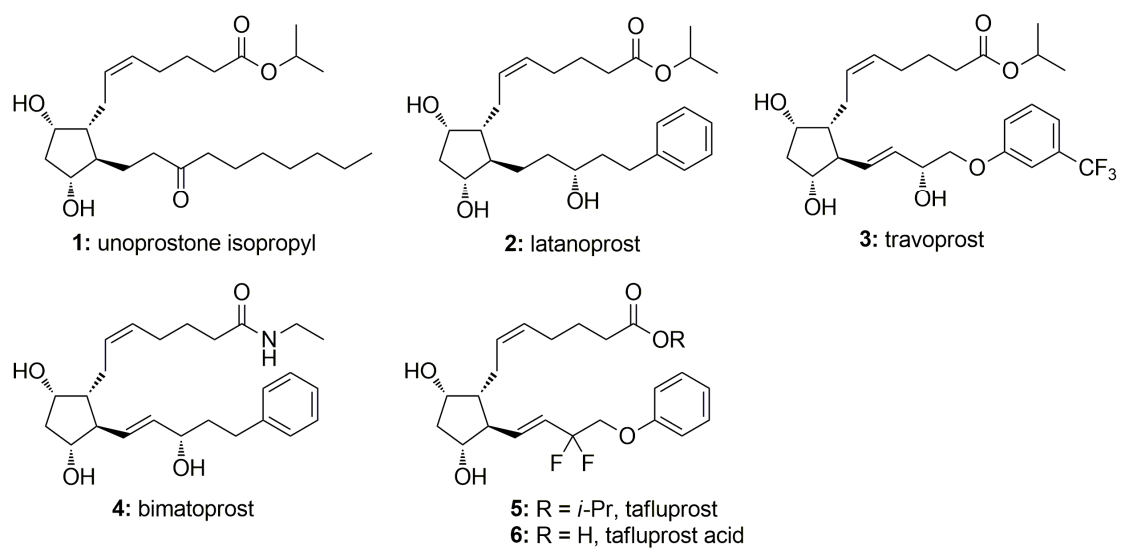

Figure 1. Chemical structures of $\mathrm{PGF}_{2 \alpha}$ analogs used in the therapy of glaucoma and ocular hypertension.

$\mathrm{PGF}_{2 \alpha}$ analogs 1-5 are mostly synthesized by one of the known variants of the Corey method, in which lower and upper side chains are sequentially attached in a specific order to a derivative of the commercially available (-)-Corey aldehyde/lactone [9,15-26]. In 2004, Matsumura et al. [9] published the first synthesis of tafluprost (5) from Corey aldehyde derivative 7 comprising a sequence of the following reactions: (a) the installation of the lower side chain ( $\omega$-chain) via a Horner-Wadsworth-Emmons condensation of the Corey aldehyde 7 with dimethyl (2-oxo-3-phenoxypropyl)phosphonate; (b) difluorination of the $\omega$-chain 15-one 8 with morpholinosulfur trifluoride to a 15-deoxy-15,15-difluoro derivative 9; (c) removal of benzoyl group with potassium carbonate; (d) reduction of the lactone moiety to a lactol $\mathbf{1 1}$ with diisobutylaluminum hydride; (e) addition of the $\alpha$-chain by Wittig olefination of $\mathbf{1 1}$ with an ylide prepared from 4-carboxybutyltriphenylphpsphonium bromide, leading to a cis-5,6-alkene; and (f) esterification of the acid 6 with isopropyl iodide in the presence of 1,8-diazabicyclo[5.4.0] undec-7-ene (Scheme 1). Thus far, however, there was no convergent methodology that would allow effective and highly diastereoselective preparation of a whole series of antiglaucoma $\mathrm{PGF}_{2 \alpha}$ analogs 2-5 from a common and structurally advanced prostaglandin intermediate.

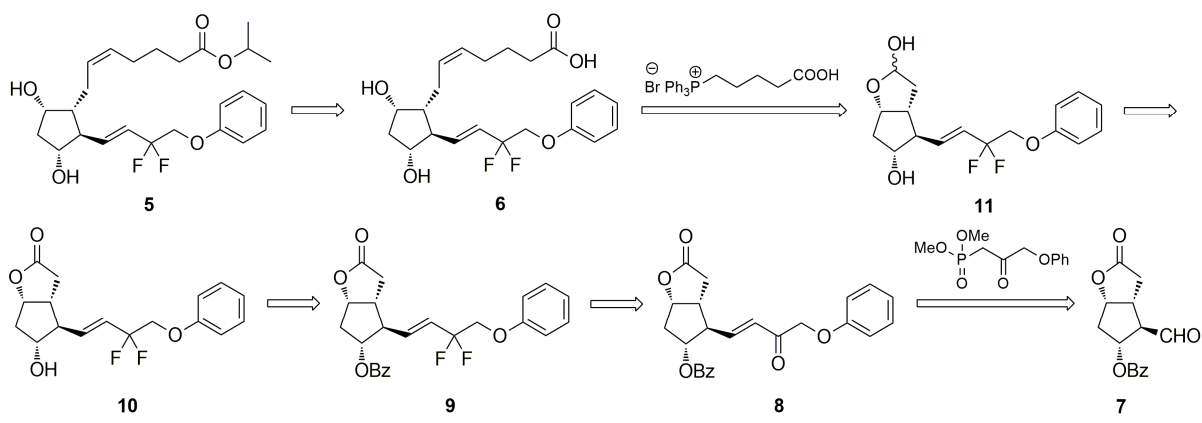

Scheme 1. Corey strategy for synthesis of tafluprost (5). 
In 2007, Martynow et al. [27] reported preparation of the structurally advanced prostaglandin phenylsulfone (5Z)-16 (Scheme 2) with the attached $\alpha$-chain possessing a carboxyl group protected by 4-methyl-2,6,7-trioxabicyclo[2.2.2] octane (methyl-OBO). The choice of the methyl-OBO carboxyl-masking group was predicted by its high stability under basic reaction conditions commonly applied during prostaglandin synthesis. On the other side, the compounds of the 4-methyl-2,6,7-trioxabicyclo[2.2.2]octane structure are easily hydrolyzed under acidic conditions to corresponding 2,2-bis(hydroxymethyl)-1-propyl esters, which can be in turn converted into other alkyl esters, like for example alkyl esters, salts or carboxylic acids. Thus, the $\omega$-chain elongation of the phenylsulfone 16 by $\mathrm{S}_{\mathrm{N}} 2$ alkylation with enantiomerically pure alkyl halides allowed the synthesis of 13,14-dihydro-15-ol $\mathrm{PGF}_{2 \alpha}$ analogs, such as latanoprost (2) [27]. The Julia-Lythgoe olefination of the sulfone $\mathbf{1 6}$ with enantiomerically pure aldehyde $\omega$-chain synthons allowed the synthesis of trans-13,14-en-15-ol $\mathrm{PGF}_{2 \alpha}$ analogs, such as travoprost (3) and bimatoprost (4) [28,29]. One of the main reasons for choosing this method of phenylsulfone $16 \omega$-chain elongation was formation of trans-13,14-ene as the only product of olefination. Compared to triphenylphosphonium or phosphonate derivatives, used in competitive Wittig or Horner-Wadsworth-Emmons olefinations, phenylsulfones are mostly stable and crystal compounds that could be easily purified to pharmaceutical grade at early stage of prostaglandin synthesis. Recently, we envisaged that the prostaglandin key intermediate $\mathbf{1 6}$ could also find the application in the convergent synthesis of tafluprost (5), depending on the structure of the aldehyde $\omega$-chain synthon and the sequence of chemical reactions needed for the $\omega$-chain elongation and functionalization (Scheme 2). The use of the same structurally advanced prostaglandin phenylsulfone 16, as a starting material in parallel syntheses of all commercially available antiglaucoma $\mathrm{PGF}_{2 \alpha}$ analogs $2-5$, would significantly reduce manufacturing costs resulting from its synthesis on an industrial scale and development of technological documentation. Since the orthoester $\mathbf{1 6}$ is stable at about $0{ }^{\circ} \mathrm{C}$ in the presence of a trace of pyridine, large amounts of 16 can be manufactured and stored in a pure form for a long time allowing the synthesis of the desired $\mathrm{PGF}_{2 \alpha}$ analog 2-5 at any time.

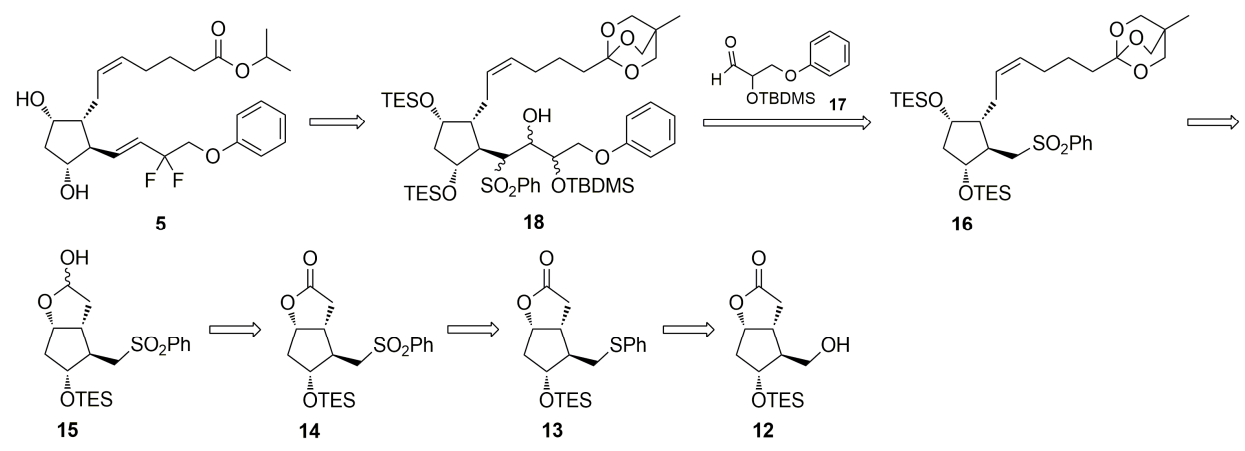

Scheme 2. Novel strategy for convergent synthesis of tafluprost (5) from prostaglandin phenylsulfone 16 and aldehyde $\omega$-chain synthon 17 , based on the reverse order of side chain attachment to the derivative of Corey lactone (12).

Glaucoma is one of the most common causes of irreversible visual impairment and blindness. It is estimated that over 60 million individuals were afflicted with open-angle and angle-closure glaucoma as of 2010, which will increase to almost 80 million by 2020 [30]. The disease affects all ethnicities, and 6.7 million people are bilaterally blind consequently. As a result of a growing demand for prostaglandin antiglaucoma drugs in the pharmaceutical market, we have developed a novel synthesis of tafluprost (5) from the advanced prostaglandin phenylsulfone $\mathbf{1 6}$ and $\alpha$-hydroxy protected aldehyde 17 (Scheme 2) based on the reversed order of side chain attachment to the Corey lactone via Wittig and Julia-Lythgoe olefinations. Since the fourth commercially available $\mathrm{PGF}_{2 \alpha}$ drug tafluprost (5) contains the trans-13,14-en-15-deoxy-15,15-difluoro moiety in the $\omega$-chain, when compared to latanoprost (2) travoprost (3) and bimatoprost (4), some modifications in an earlier developed approach for the highly diastereoselective construction of the $\omega$-chain allylic moiety to incorporate the desired C-15 difluorinated center needed to be developed. 
Most common $\mathrm{PGF}_{2 \alpha}$ analogs, latanoprost (2), travoprost (3), bimatoprost (4) and tafluprost (5), are licensed for the reduction of elevated intraocular pressure in patients with open angle glaucoma and ocular hypertension, but their non approved use as eyelash enhancers is becoming popular, especially in patients with eyelashes hypotrichosis [31]. There are other prostaglandin derivatives, such as tafluprost methyl ester (32) [32,33] and tafluprost ethyl amide (33) [34], that could be used in antiglaucoma ophthalmic compositions or cosmetics because they appear capable of IOP reduction and influencing eyelash growth; however, their efficacy and safety has not been fully studied and evaluated yet. Therefore, there is also a strong demand for a convenient process that is suitable for preparation of high purity tafluprost methyl ester (32) and tafluprost ethyl amide (33) on a commercial scale.

\section{Results and Discussion}

Based on our previous work on $\omega$-chain elongation of the prostaglandin phenylsulfone $\mathbf{1 6}$ with the aldehyde $\omega$-chain synthons of travoprost and bimatoprost $[28,29]$, we envisaged that the Julia-Lythgoe olefination [35-37] of the sulfone $\mathbf{1 6}$ with the $\alpha$-hydroxy protected aldehyde $\mathbf{1 7}$ should give a mixture of $\beta$-hydroxysulfones 18 (Scheme 2), which via reductive dehydroxy-desulfonylation and deprotection/protection of methyl-OBO and hydroxyl groups followed by oxidation of the 15-ol and deoxydifluorination of 13,14-en-15-one could enable construction of the $\omega$-chain trans-13,14-en-15-deoxy-15,15-difluoro moiety. Irrespective of stereochemical configuration of the C-2 carbon atom in the aldehyde 17, corresponding to the C-15 carbon atom in tafluprost (5), the deprotection of tert-butyldimethylsilyl protected hydroxyl group and its oxidation to a 15-one followed by its deoxydifluorination should lead to the non-chiral C-15 gem-difluorinated carbon atom in the final prostaglandin analog 5 . Therefore, for economic reasons, the 2-(tert-butyl-dimethylsilyloxy)3-phenoxypropanal (17) used for the construction of the $\omega$-chain of tafluprost (5) should be prepared as a racemate.

\subsection{Synthesis of the Aldehyde $\omega$-Chain Synthon $\mathbf{1 7}$}

To the best of our knowledge, the aldehyde $\omega$-chain synthon $\mathbf{1 7}$ has never been obtained in a racemic form. In 2010, Lin et al. reported the preparation of optically active $(R)-\mathbf{1 7}$ based on epoxide ring-opening of $(R)$-benzyl glicydyl ether with phenol in the presence of organic base [38]. The protection of the resulting secondary alcohol with tert-butyldimethylsilyl trifluoromethanesulfonate followed by removing of benzyl group and Dess-Martin oxidation of the (S)-25 gave the optically active aldehyde $(R)-\mathbf{1 7}$. Although the route described above could be applied to supply of the racemic aldehyde 17, the cost of benzyl glicydyl ether and the use of heavy metal catalyzed hydrogenation process limit its large-scale application in the pharmaceutical industry. Therefore, a more industrially applicable procedure for synthesis of racemic 2-(tert-butyldimethylsilyloxy)-3-phenoxypropanal (17) (Scheme 3) was developed based on a synthetic route applied earlier for the preparation of the aldehyde $\omega$-chain synthon of travoprost [28].

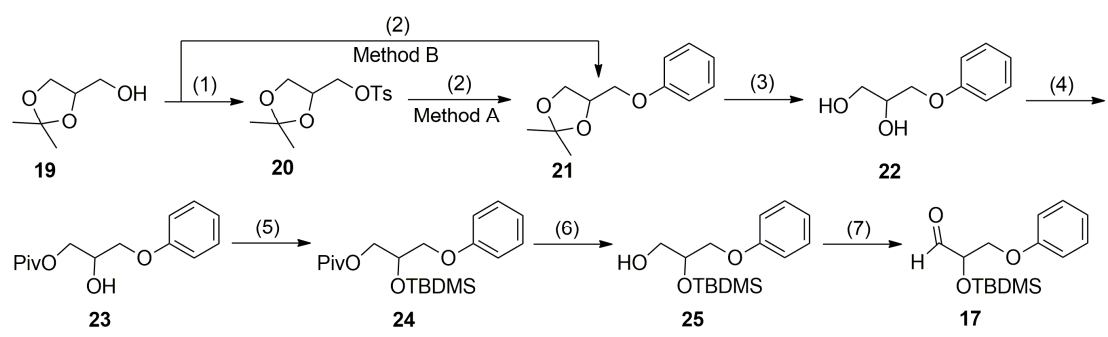

Scheme 3. Synthesis of the racemic aldehyde $\omega$-chain synthon 17. Conditions: (1) $\mathrm{TsCl}, \mathrm{Py}, 0{ }^{\circ} \mathrm{C}$ for $10 \mathrm{~min}$, then r.t. overnight, $99 \%$ yield; (2) Method A: phenol, $\mathrm{NaOH}, \mathrm{EtOH}-\mathrm{H}_{2} \mathrm{O}$, reflux for $30 \mathrm{~h}, 90 \%$ yield. Method B: phenol, $\mathrm{PPh}_{3}$, DIAD, toluene, $99-100{ }^{\circ} \mathrm{C}$ for $18 \mathrm{~h}, 96 \%$ yield; (3) $1.0 \mathrm{M} \mathrm{HCl}$, acetone, $70{ }^{\circ} \mathrm{C}$ for $1 \mathrm{~h}, 98 \%$ yield; (4) PivCl, $\mathrm{Py}-\mathrm{CH}_{2} \mathrm{Cl}_{2}, 0{ }^{\circ} \mathrm{C}$ for $1 \mathrm{~h}$, then $1.5 \mathrm{~h}$ at r.t., $93 \%$ yield; (5) TBDMSCl, $\mathrm{ImH}, \mathrm{DMF}, 0^{\circ} \mathrm{C}$ for $15 \mathrm{~min}$, then $18 \mathrm{~h}$ at r.t., $94 \%$ yield; (6) DIBAL- $\mathrm{H}, \mathrm{CH}_{2} \mathrm{Cl}_{2},-78{ }^{\circ} \mathrm{C}$ for $20 \mathrm{~min}$, then $2 \mathrm{~h}$ at r.t., $95 \%$ yield; (7) DMP, $\mathrm{NaHCO}_{3}, \mathrm{CH}_{2} \mathrm{Cl}_{2}, 0^{\circ} \mathrm{C}$ for $15 \mathrm{~min}$, then $1 \mathrm{~h}$ at r.t., $94 \%$ yield. 


\subsection{Synthesis of Tafluprost (5), Tafluprost Methyl Ester (32) and Tafluprost Ethyl Amide (33)}

The efficient $\omega$-chain elongation of phenylsulfone $\mathbf{1 6}$ with sterically hindered aldehyde $\mathbf{1 7}$ to the mixture of diastereoisomeric $\beta$-hydroxysulfones 18 was achieved by using freshly prepared LDA (Scheme 4). Since significant losses of $\mathbf{1 8}$ were observed during column chromatography due to limited stability of the methyl-OBO protecting group on silica gel, the crude mixture of $\beta$-hydroxysulfones 18 was subjected to reductive elimination with a fresh $20 \%$ sodium amalgam to afford the methyl-OBO protected prostaglandin precursor 26. It is well documented that sodium amalgam reduction of aliphatic $\alpha$-hydroxysulfones furnishes olefins having the trans configuration of the $\omega$-chain 13,14-double bond [36]. The phosphate-buffered conditions of Trost [39] were used to ensure the optimal $\mathrm{pH}$ conditions and prevent deprotection of the cyclopentane hydroxyl groups. Similarly to the methyl-OBO protected $\beta$-hydroxysulfones 18 , the methyl-OBO protected prostaglandin intermediate $\mathbf{2 6}$ was not purified by means of silica gel column chromatography. Significantly, there was no need for purification of the prostaglandin intermediates 18 and 26, which was a major advantage for any future scale-up. The triethylsilyl and methyl-OBO masking groups in prostaglandin precursor $\mathbf{2 6}$ were all removed under the action of pyridinium $p$-toluenesulfonate (PPTS) in a mixture of $\mathrm{CH}_{2} \mathrm{Cl}_{2}-\mathrm{MeOH}$, immediately followed by esterification of free hydroxyl groups with acetic anhydride to the diastereoisomeric 2,2-bis(acetoxymethyl)propyl ester $\mathbf{2 8 a} / \mathbf{b}$. The compound $\mathbf{2 8 a} / \mathbf{b}$ was purified by silica gel flash chromatography; however, only a sample of one of the diastereoisomers was isolated and identified by spectroscopic methods. The unique stereochemical features of the Julia-Lythgoe olefination allowed preserving the relative cis / trans stereochemistry of side chains in the isolated prostaglandin intermediate. Additionally, the appropriately functionalized aldehyde $\omega$-chain synthon $\mathbf{1 7}$ with bulky tert-butyldimethylsilyl group at C-2, in agreement with literature data for olefination with aldehydes with steric encumbrance [40], afforded trans-13,14-alkenes $\mathbf{2 8 a} / \mathbf{b}$ as the only products of Julia-Lythgoe olefination. The tert-butyldimethylsilyl protecting group was removed with camphor-10-sulfonic acid (CSA) to afford a mixture of diastereoisomeric 15-OH prostaglandin derivatives $29 a / \mathbf{b}$. Similarly to the ester $\mathbf{2 8 a} \mathbf{a} \mathbf{b}$, silica gel flash chromatography allowed isolation and identification by spectroscopic methods of only one C-15 epi-isomer from the mixture of diastereoisomeric alcohols $29 \mathbf{a} / \mathbf{b}$. Most importantly, since the chirality of C-15 carbon atom disappears during tafluprost (5) final synthesis, there was no need for purification and separation of the diastereoisomeric prostaglandin intermediates $27 a / b, 28 a / b$ and $29 a / b$, which additionally was a major advantage for any future scale-up. A mixture of diastereiosmeric alcohols $29 \mathbf{a} / \mathbf{b}$ was then oxidized with Dess-Martin periodinane [41] to a 15-keto intermediate 30. The use of Dess-Martin periodinane avoided some difficulties encountered with other methods, e.g., oxidation of 13,14-en-15-ols with toxic and unstable DDQ [19], such as adverse products, long reaction times, difficult workup procedures or the need to apply a large excess of the oxidizing agent. Additionally, the product of the oxidation route could be easily purified with short column chromatography. The structure of $\mathbf{3 0}$ was confirmed by spectroscopic methods.

Although a gem-difluoride unit has been drawn more attention recently in medicinal chemistry, there is no general method to prepare allyl difluorides from the corresponding 13,14-en-15-ones efficiently [42,43]. Therefore, we studied the reaction using some commercially available fluorinating agents, such as (diethylamino)sulfur trifluoride (DAST), (diethylamino)-difluorosulfonium tetrafluoroborate (XtalFluor-E), difluoro(morpholino)sulfonium tetrafluoro-borate (XtalFluor-M), bis(2-methoxyethyl)aminosulfur trifluoride (Deoxo-Fluor) and 4-tert-butyl-2,6-dimethylphenylsulfur trifluoride (Fluolead). After exploring various possibilities, Deoxo-Fluor was found to be the best reagent of choice. Thus, the fluorination reaction of 13,14-en-15-one 30 with Deoxo-Fluor in boiling $\mathrm{CH}_{2} \mathrm{Cl}_{2}$ for $24 \mathrm{~h}$ afforded geminal difluoride 31 with $78 \%$ yield. 

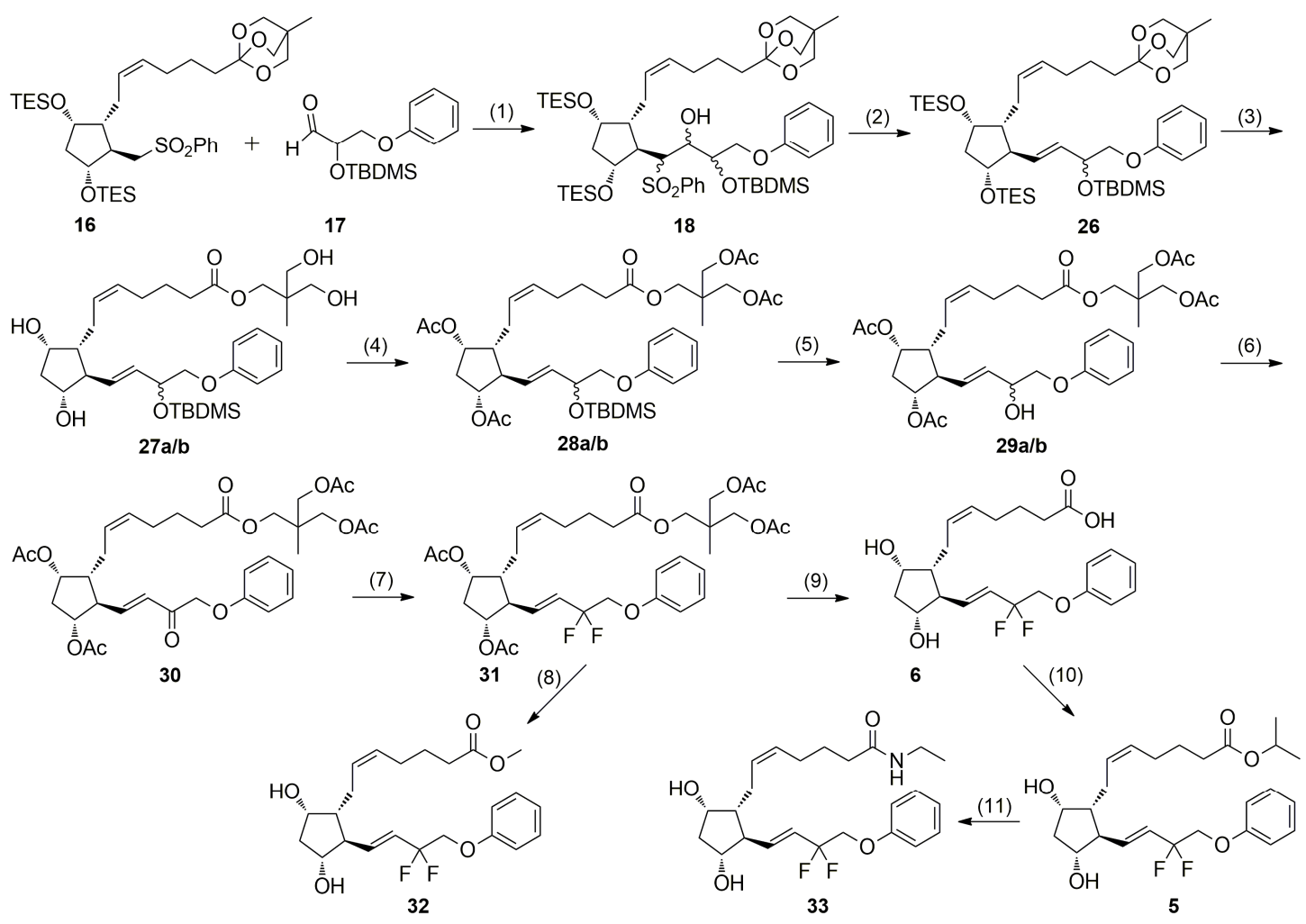

Scheme 4. Synthesis of tafluprost (5), tafluprost methyl ester (32) and tafluprost ethylamide (33) from phenylsulfone 16 and aldehyde 17. Reagents and conditions: (1) LDA, THF, $-78{ }^{\circ} \mathrm{C}, 1 \mathrm{~h} ;(2) \mathrm{Na} / \mathrm{Hg}$, $\mathrm{Na}_{2} \mathrm{HPO}_{4}, \mathrm{MeOH}, 0{ }^{\circ} \mathrm{C}$ for $60 \mathrm{~min}$, then $16 \mathrm{~h}$ at r.t.; (3) PPTS, $\mathrm{CH}_{2} \mathrm{Cl}_{2}, \mathrm{MeOH}, 3 \mathrm{~h}$ at r.t., $79 \%$ yield from 16; (4) TEA, DMAP, $\mathrm{Ac}_{2} \mathrm{O}, \mathrm{CH}_{2} \mathrm{Cl}_{2}, 97 \%$ yield; (5) $\mathrm{CAS}, \mathrm{MeOH}, \mathrm{CH}_{2} \mathrm{Cl}_{2}, 7$ h at r.t., $82 \%$ yield; (6) DMP, $\mathrm{NaHCO}_{3}, \mathrm{CH}_{2} \mathrm{Cl}_{2}, 99 \%$ yield; (7) Deoxo-Fluor, $\mathrm{CH}_{2} \mathrm{Cl}_{2} ; 0{ }^{\circ} \mathrm{C}$ for $15 \mathrm{~min}$, then reflux for $24 \mathrm{~h}$, $78 \%$ yield; (8) $\mathrm{K}_{2} \mathrm{CO}_{3}, \mathrm{MeOH}, 24 \mathrm{~h}$ at r.t., 76\% yield; (9) $\mathrm{LiOH} \mathrm{H}_{2} \mathrm{O}, \mathrm{MeOH}$, overnight, 98\% yield; (10) $i$-PrI, DBU, acetone, $21 \mathrm{~h}$ at r.t., $83 \%$ yield; (11) $\mathrm{EtNH}_{2}, \mathrm{H}_{2} \mathrm{O}, 60 \mathrm{~h}$ at r.t.; $85 \%$ yield.

The deprotection of acetyl and 2,2-bis(acetoxymethyl)propyl groups in 31 by means of potassium carbonate in $\mathrm{MeOH}$ yielded tafluprost methyl ester (33) in 76\% yield. The ester $\mathbf{3 1}$ was hydrolyzed with lithium hydroxide monohydrate and, after acidification with citric acid, tafluprost acid (6) was isolated in almost quantitative yield. In the final step of the synthesis, acid $\mathbf{6}$ was successfully esterified with $i$-Pr/DBU in acetone to afford tafluprost (5). The crude 5 was purified by silica gel flash chromatography and identified by spectroscopic methods. The $\alpha$-chain allylic carbons C-4 and C-7 of tafluprost are seen in the ${ }^{13} \mathrm{C}-\mathrm{NMR}$ spectrum as two singlets located at 25.7 and $26.6 \mathrm{ppm}$, which is characteristic for 5,6-cis diastereoisomers of $\mathrm{PGF}_{2 \alpha}$ analogs [27]. The fluorination of C-15 carbonyl group in 30 with Deoxo-Fluor leads to several significant effects in NMR spectra, which are important from the point of view of structure conformation/determination. The biggest change related to the replacement of oxygen with two fluorine atoms leads to strong shielding increase of C-15 nucleus by ca. $80 \mathrm{ppm}$ and appearance of this signal in ${ }^{13} \mathrm{C}-\mathrm{NMR}$ spectrum as a triplet with relative large ${ }^{1} J(\mathrm{C}-\mathrm{F})$ coupling of ca. $240 \mathrm{~Hz}$. Similar but rather smaller effects are observed for neighboring protons and carbons. In the case of ${ }^{1} \mathrm{H}-\mathrm{NMR}$ spectrum, transition from 30 to 5 leads to shielding increase of all protons in $\omega$-chain by ca. $0.3-0.5 \mathrm{ppm}$. The same is true for ${ }^{13} \mathrm{C}$ nuclei but the shielding effects are stronger and vary in the range from 3 to $9 \mathrm{ppm}$. The biggest one (ca. $9 \mathrm{ppm}$ ) is observed for C-13 carbon. Two- and three- bonds C-F couplings visible in ${ }^{13} \mathrm{C}-\mathrm{NMR}$ spectrum as triplets are of typical values for such difluorine compounds containing double bond [44] and are as follows: $8.8 \mathrm{~Hz}, 25.0 \mathrm{~Hz}$ and $34.9 \mathrm{~Hz}$ for C-13, C-14 and C-16 nuclei, respectively. Complete ${ }^{1} \mathrm{H} /{ }^{13} \mathrm{C}$ and ${ }^{19} \mathrm{~F}-\mathrm{NMR}$ chemical shifts assignment for tafluprost (5) is presented in the Experimental Section 3.6.10. 
Most synthetic procedures used to attain prostamides $\mathrm{F}_{2 \alpha}$ proceed via prostaglandin acid and its esterification to the corresponding isopropyl ester, subsequently followed by amidation with ethylamine [24,25]. Thus, tafluprost (5) was successfully amidated to tafluprost ethyl amide (33) with ethylamine aqueous solution. The crude 33 was purified by silica gel flash chromatography and identified by spectroscopic methods.

\section{Experimental Section}

\subsection{General Information}

D,L-2,2-Dimethyl-4-(hydroxymethyl)-1,3-dioxolane (98\%), phenol (99\%), Dess-Martin periodinane $(97 \%)$, trimethyl acetyl chloride (99\%), tert-butyldimethylsilyl chloride $(97 \%)$, imidazole $(99 \%)$, diisobutylaluminum hydride solution (1.0 $\mathrm{M}$ in toluene), diisopropylamine (99.5\%), butyllithium solution (1.6 M in hexanes), sodium mercury amalgam (99.9\% trace metal basis, Na $20 \%$ beads), p-toluenesulfonyl chloride (98\%), diisopropyl azodicarboxylate (97\%), triphenylphosphine (99\%), pyridinium $p$-toluenesulfonate $(98 \%)$, acetic anhydride (99\%), triethylamine $(99 \%)$, 4-(dimethylamino)pyridine (99\%), camphor-10-sulfonic acid (98\%), bis(2-methoxyethyl)aminosulfur trifluoride solution (Deoxo-Fluor solution, 50\% in THF), 1,8-diazabicyclo[5.4.0]undec-7-ene (99\%), 2-iodopropane (99\%), ethylamine (70\% in $\left.\mathrm{H}_{2} \mathrm{O}\right)$, pyridine (anhydrous, $\left.99.8 \%\right), \mathrm{N}, \mathrm{N}$-dimethylformamide (anhydrous, 99.5\%), were purchased from Sigma Aldrich and Iris Biotech Gmbh chemical companies. 1-[(Z)-6$\{(1 R, 2 R, 3 R, 5 S)-2-[($ Phenyl-sulfonyl)methyl]- 3,5-bis(triethylsilyloxy)cyclopentyl\}hex-4-enyl-4-methyl2,6,7-trioxabicyclo[2.2.2]-octane [27] was manufactured by Pharmaceutical Research Institute (Warsaw, Poland). Reactions requiring anhydrous conditions were carried out using flame-dried glassware, which was cooled to $20^{\circ} \mathrm{C}$ in a desiccators under an argon atmosphere. All moisture- or air-sensitive reactions were run under an argon atmosphere. Air-sensitive reagents were transferred via syringe or cannula and were introduced to the apparatus through rubber septa. Solids were introduced under a positive pressure of argon. Reactions were cooled via external cooling baths: ice water $\left(0^{\circ} \mathrm{C}\right)$ or dry-acetone $\left(-78^{\circ} \mathrm{C}\right)$. Heating was accomplished by either a heating mantle or silicone oil bath. Deionized water was used for all aqueous extractions and for obtaining all aqueous solutions. Solvents were removed under reduced pressure using standard rotary evaporators. The course of all reactions and the purity of products were checked by thin-layer chromatography (TLC). Analytical TLC was performed on silica gel DC-Alufolien Kieselgel $60 \mathrm{~F}_{254}$ (Merck, Darmstadt, Germany) with mixtures of hexanes, ethyl acetate, dichloromethane, methanol, acetonitrile and toluene in various ratios as developing systems. Compounds were detected by spraying the plates with $1 \% \mathrm{Ce}\left(\mathrm{SO}_{4}\right)_{2} / 2 \%$ $\mathrm{H}_{3}\left[\mathrm{P}\left(\mathrm{Mo}_{3} \mathrm{O}_{10}\right)_{4}\right]$ in $10 \% \mathrm{H}_{2} \mathrm{SO}_{4}$ followed by heating to $120^{\circ} \mathrm{C}$. Preparative column chromatography was carried out on silica gel (Kieselgel 60, 40-63 $\mu \mathrm{m}, 230-400$ mesh, Merck) with mixtures of ethyl acetate, hexanes, dichloromethane, methanol, tert-butyl-methyl ether in varying ratios as eluents. Flash chromatography was run with a positive air pressure generated by handheld, pear-shaped rubber pumps.

\subsection{Optical Rotation}

Optical rotations were measured with a Perkin Elmer 341 automatic polarimeter in $\mathrm{Me}_{2} \mathrm{CO}$ or $\mathrm{CH}_{2} \mathrm{Cl}_{2}$ solutions as the solvents with percent concentrations.

\subsection{FT-IR Spectroscopy}

IR spectra were taken for liquid films or KBr pellets on a Nicolet Impact 410 FT-IR spectrophotometer.

\subsection{NMR Spectroscopy}

The NMR spectra of all the compounds were measured in $\mathrm{CDCl}_{3}$ solutions with a Varian VNMRS-600 (600 MHz) or Varian VNMRS-500 (500 MHz) at temperature $298 \mathrm{~K}$ using TMS (for ${ }^{1} \mathrm{H} /{ }^{13} \mathrm{C}-\mathrm{NMR}$ measurements) or $\mathrm{CCl}_{3} \mathrm{~F}$ (for ${ }^{19} \mathrm{~F}-\mathrm{NMR}$ measurements) as internal standards. Concentration of all solutions used for measurements was about $20-30 \mathrm{mg}$ of compounds in $0.6 \mathrm{~mL}$ of solvent. 


\subsection{Mass Spectrometry}

HRMS spectra were recorded on an AMD 604 Inectra Gmbh spectrometer or a Mariner PE Biosystem ESI-TOF spectrometer.

\subsection{Syntheses}

The synthesis of the aldehyde $\omega$-chain synthon 17 from the commercially available D,L-1,2-isopropylidene glycerol (19) is shown in Scheme 3. The detailed descriptions of the preparation of compounds 20-25 and $\mathbf{1 7}$ as well as their physical and spectroscopic data are provided in the Supplementary Materials.

3.6.1. 1-\{(Z)-6-[(1R,2R,3R,5S)-2-[(1R/1S,2R/2S,3R/3S)-3-(tert-Butyldimethylsilyloxy)-4-phenoxy-1(phenylsulfonyl)butyl]-3,5-bis(triethylsilyloxy)cyklopentyl]hex-4-enyl\}-4-methyl-2,6,7-

trioxabicyclo-[2.2.2]octane (18)

$n$-BuLi (28.6 mL, $45.8 \mathrm{mmol}, 1.6 \mathrm{M}$ in hexanes) was added dropwise to a solution of diisopropylamine $(7.96 \mathrm{~mL}, 45.8 \mathrm{mmol})$ in anhydrous THF $(12 \mathrm{~mL})$ at $-78{ }^{\circ} \mathrm{C}$ under an argon atmosphere. After $15 \mathrm{~min}$ at $-78^{\circ} \mathrm{C}$, the phenylsulfone $16(21.0 \mathrm{~g}, 30.2 \mathrm{mmol})$ in anhydrous THF $(40 \mathrm{~mL})$ was added dropwise with vigorous stirring. The reaction mixture was stirred at $-60^{\circ} \mathrm{C}$ for $30 \mathrm{~min}$ and the aldehyde $\mathbf{1 7}(14.0 \mathrm{~g}, 50.0 \mathrm{mmol})$ in anhydrous THF $(10 \mathrm{~mL})$ was added dropwise. After being stirred at $-60{ }^{\circ} \mathrm{C}$ for another $30 \mathrm{~min}$, TLC analysis $(6 \% \mathrm{MeCN} /$ toluene) indicated disappearance of the starting phenylsulfone 16. The cold reaction was quenched with saturated aqueous $\mathrm{NaCl}$ solution $(30 \mathrm{~mL})$. The resulting layers were separated and the aqueous phase was extracted with THF $(3 \times 25 \mathrm{~mL})$. The combined organic extracts were washed with brine $(150 \mathrm{~mL})$, dried over $\mathrm{Na}_{2} \mathrm{SO}_{4}$, filtered and concentrated in vacuo. The crude product was carefully dried in vacuo to yield a mixture of diastereoisomeric hydroxysulfones 18 ( $38.2 \mathrm{~g}$ ), as a yellow oil. The hydroxysulfones 18 were directly used for the next step without further purification.

3.6.2. 1-\{(4Z)-6-[(1R,2R,3R,5S)-2-[(1E,3R/3S)-3-(tert-Butyldimethylsilyloxy)-4-(phenoxy)but1-enyl]-3,5-bis(triethylsilyloxy)cyclopentyl]hex-4-enyl\}-4-methyl-2,6,7-trioxabicyclo[2.2.2] octane (26)

The crude mixture of diastereoisomeric hydroxysulfones 18 ( $38.2 \mathrm{~g}$ ) was dissolved in THF ( $25 \mathrm{~mL})$ and saturated methanolic solution of $\mathrm{Na}_{2} \mathrm{HPO}_{4}(120 \mathrm{~mL})$ was added in one portion. On cooling to $0{ }^{\circ} \mathrm{C}$ under an argon atmosphere, sodium amalgam $(20 \%, 25.0 \mathrm{~g}, 217.4 \mathrm{mmol} \mathrm{Na})$ was added portionwise over $60 \mathrm{~min}$ with vigorous stirring. The cooling bath was removed and the resulting suspension was stirred at room temperature for $16 \mathrm{~h}$ to disappearance of the starting hydroxysulfones 18 (TLC, $\mathrm{MeCN} /$ toluene 1:1). The solution was decanted from the remaining amalgam and concentrated under reduced pressure. The residue was diluted with $\mathrm{H}_{2} \mathrm{O}(60 \mathrm{~mL})$ and AcOEt $(60 \mathrm{~mL})$. The resulting layers were separated and the aqueous phase was extracted with AcOEt $(3 \times 50 \mathrm{~mL})$. The combined organic extracts were washed with brine $(150 \mathrm{~mL})$ and dried over anhydrous $\mathrm{Na}_{2} \mathrm{SO}_{4}$. Filtration and evaporation in vacuo furnished the crude product $\mathbf{2 6}$ (38.1 g) as a light yellow oil. The crude olefin 26 was directly used for the next step without further purification.

3.6.3. 2,2-Bis(hydroxymethyl)propyl (5Z)-7-\{(1R,2R,3R,5S)-2-[(1E,3R/3S)-3-(tertbutyldimethylsilylo-xy)-4-(phenoxy)but-1-enyl]-3,5-dihydroxycyclopentyl\}hept-5-enoate (27a/b)

PPTS $(28.0 \mathrm{~g}, 111.42 \mathrm{mmol})$ was added to a solution of the crude silyl protected prostaglandin derivatives 26 (38.1 g) in a mixture of $\mathrm{CH}_{2} \mathrm{Cl}_{2}-\mathrm{MeOH}(1: 1,300 \mathrm{~mL})$. The resulting brown solution was stirred for $3 \mathrm{~h}$, whereupon brine $(150 \mathrm{~mL})$ and saturated aqueous solution $\mathrm{NaHCO}_{3}(150 \mathrm{~mL})$ were added. After being stirred for $15 \mathrm{~min}$, the organic solvents were evaporated under reduced pressure. The residue was extracted with $\mathrm{AcOEt}(3 \times 100 \mathrm{~mL})$. The combined organic extracts were dried over anhydrous $\mathrm{Na}_{2} \mathrm{SO}_{4}$. Filtration and evaporation in vacuo furnished the crude tetraol $(24.8 \mathrm{~g})$. Purification by silica gel flash chromatography with gradient elution $1 \%-6 \% \mathrm{MeOH}-\mathrm{CH}_{2} \mathrm{Cl}_{2}$ afforded a sample of prostaglandin analog $(+)-27 \mathbf{a}(84 \mathrm{mg})$ and an inseparable mixture of diastereoisomeric 
tetraols $27 \mathbf{a} / \mathbf{b}\left(14.5 \mathrm{~g}, 79 \%\right.$ yield from phenylsulfone 16) as a light yellow viscous oil. $(+)-27 \mathbf{a}: R_{\mathrm{f}}=0.42$ (50\% $\mathrm{CH}_{3} \mathrm{CN} /$ toluene). $[\alpha]_{D}^{20}=+17.72$ (c 1.0, $\mathrm{CH}_{2} \mathrm{Cl}_{2}$ ). FT-IR (thin film) $v\left(\mathrm{~cm}^{-1}\right)$ : 3393, 2946, 2929, 2899, 2857, 1731, 1717, 1600, 1587, 1497, 1471, 1388, 1301, 1248, 1172, 1143, 1044, 974, 837, 810, 779, 754, 733, 692, 596, 509. ${ }^{1} \mathrm{H}-\mathrm{NMR}\left(\mathrm{CDCl}_{3}, 600 \mathrm{MHz}\right) \delta(\mathrm{ppm}): 0.10$ (two s, $\left.6 \mathrm{H},\left(\mathrm{CH}_{3}\right)_{2} \mathrm{Si}\right), 0.84(\mathrm{~s}, 3 \mathrm{H}$, $\left(-\mathrm{C}\left(\mathrm{CH}_{3}\right)\left(\mathrm{CH}_{2} \mathrm{OH}\right)_{2}\right), 0.91\left(\mathrm{~s}, 9 \mathrm{H},\left(\mathrm{CH}_{3}\right)_{3} \mathrm{C}-\mathrm{Si}\right), 1.57(\mathrm{~m}, 1 \mathrm{H}$, cyclopentane $\mathrm{CH}-1), 1.71(\mathrm{~m}, 2 \mathrm{H}, \alpha$-chain $\left.\mathrm{CH}_{2}-3\right), 1.81$ (m, $1 \mathrm{H}$, one of the cyclopentane $\mathrm{CH}_{2}-4$ group), 2.05-2.20 (m, 4H, $\alpha$-chain $\mathrm{CH}_{2}-4$, one of the $\alpha$-chain $\mathrm{CH}_{2}-7$ group, one of the cyclopentane $\mathrm{CH}_{2}-4$ group), 2.32 (m, $1 \mathrm{H}$, one of the $\alpha$-chain $\mathrm{CH}_{2}-7$ group), 2.33-2.40 (m, 3H, $\alpha$-chain $\mathrm{CH}_{2}-2$ and cyclopentane $\left.\mathrm{CH}-2\right), 3.52\left(\mathrm{~d}, J=11.5 \mathrm{~Hz}, 2 \mathrm{H},-\mathrm{CH}_{2} \mathrm{OH}\right)$, $3.57\left(\mathrm{~d}, \mathrm{~J}=11.5 \mathrm{~Hz}, 2 \mathrm{H},-\mathrm{CH}_{2} \mathrm{OH}\right), 3.86\left(\mathrm{~d}, J=6.0 \mathrm{~Hz}, 2 \mathrm{H}, \omega\right.$-chain $\left.\mathrm{CH}_{2}-4\right), 3.99(\mathrm{~m}, 1 \mathrm{H}$, cyclopentane $\mathrm{CH}-3), 4.15-4.20\left(\mathrm{~m}, 3 \mathrm{H},-\mathrm{OCH}_{2} \mathrm{C}\left(\mathrm{CH}_{3}\right)\left(\mathrm{CH}_{2} \mathrm{OH}\right)_{2}\right.$ and cyclopentane $\left.\mathrm{CH}-5\right), 4.51(\mathrm{~m}, 1 \mathrm{H}, \omega-\mathrm{chain} \mathrm{CH}-3)$, 5.36 (m, 1H, $\alpha$-chain CH-5), 5.42 (m, 1H, $\alpha$-chain CH-6), 5.62-5.68 (m, 2H, w-chain CH-1 and CH-2), $6.88(\mathrm{~m}, 2 \mathrm{H}$, aromatic $\mathrm{CH}-2$ and $\mathrm{CH}-6), 6.93(\mathrm{~m}, 1 \mathrm{H}$, aromatic $\mathrm{CH}-4), 7.27(\mathrm{~m}, 2 \mathrm{H}$, aromatic $\mathrm{CH}-3$ and $\mathrm{CH}-5) .{ }^{13} \mathrm{C}-\mathrm{NMR}\left(150 \mathrm{MHz}, \mathrm{CDCl}_{3}\right) \delta(\mathrm{ppm}):-4.7\left(\mathrm{CH}_{3}-\mathrm{Si}\right),-4.6\left(\mathrm{CH}_{3}-\mathrm{Si}\right), 16.9\left(-\mathrm{C}\left(\mathrm{CH}_{3}\right)\left(\mathrm{CH}_{2} \mathrm{OH}\right)_{2}\right)$, $18.4\left(\left(\mathrm{CH}_{3}\right)_{3} \underline{\mathrm{C}}-\mathrm{Si}\right), 24.8$ ( $\alpha$-chain $\left.\mathrm{C}-3\right), 25.8\left(3 \mathrm{C},\left(\mathrm{CH}_{3}\right)_{3} \mathrm{C}-\mathrm{Si}\right), 26.1$ ( $\alpha$-chain $\left.\mathrm{C}-7\right), 26.6(\alpha$-chain $\mathrm{C}-4)$, $33.6(\alpha$-chain $\mathrm{C}-2), 40.6\left(-\mathrm{C}\left(\mathrm{CH}_{3}\right)\left(\mathrm{CH}_{2} \mathrm{OH}\right)_{2}\right), 42.8$ (cyclopentane $\left.\mathrm{C}-4\right), 50.6$ (cyclopentane $\left.\mathrm{C}-1\right), 56.0$ (cyclopentane C-2), $66.5\left(-\mathrm{OCH}_{2} \mathrm{C}\left(\mathrm{CH}_{3}\right)\left(\mathrm{CH}_{2} \mathrm{OH}\right)_{2}\right), 67.5\left(2 \mathrm{C},-\mathrm{OCH}_{2} \mathrm{C}\left(\mathrm{CH}_{3}\right)\left(\mathrm{CH}_{2} \mathrm{OH}\right)_{2}\right), 71.6(\omega$-chain C-3), 72.2 ( $\omega$-chain C-4), 73.6 (cyclopentane C-5), 78.4 (cyclopentane C-3), 114.4 (2C, aromatic C-2 and C-6), 120.7 (aromatic C-4), 129.3 ( $\alpha$-chain CH-6), 129.4 (2C, aromatic C-3 and C-5), $129.5(\alpha$-chain CH-5), 131.0 ( $\omega$-chain C-2), 133.0 ( $\omega$-chain C-1), 158.8 (aromatic C-1), $174.7(\mathrm{C}=\mathrm{O})$. HRMS (ESI): calcd. for $\mathrm{C}_{33} \mathrm{H}_{54} \mathrm{O}_{8} \mathrm{NaSi}[\mathrm{M}+\mathrm{Na}]^{+}$629.3486; found 629.3474 .

3.6.4. 2,2-Bis(acetoxymethyl)propyl (5Z)-7-\{(1R,2R,3R,5S)-3,5-diacetoxy-2-[(1E,3R/3S)-3(tert-butyldi-methylsilyloxy)-4-(phenoxy)but-1-enyl]cyclopentyl\}hept-5-enoate (28a/b)

TEA (23.7 mL, $173.3 \mathrm{mmol})$, DMAP $(0.2 \mathrm{~g})$ and $\mathrm{Ac}_{2} \mathrm{O}(8.2 \mathrm{~mL}, 86.5 \mathrm{~mol})$ were added to a solution of the diastereoisomeric prostaglandin derivatives $27 \mathbf{a} / \mathbf{b}(10.5 \mathrm{~g}, 17.3 \mathrm{mmol})$ in $\mathrm{CH}_{2} \mathrm{Cl}_{2}(100 \mathrm{~mL})$. The mixture was stirred for $1 \mathrm{~h}$ at room temperature prior the addition of saturated aqueous solution $\mathrm{NH}_{4} \mathrm{Cl}(100 \mathrm{~mL})$. The resulting layers were separated and the aqueous phase was extracted with $\mathrm{CH}_{2} \mathrm{Cl}_{2}(3 \times 50 \mathrm{~mL})$. The combined organic extracts were washed with saturated aqueous solution $\mathrm{NaHCO}_{3}(50 \mathrm{~mL})$ and dried over anhydrous $\mathrm{MgSO}_{4}$. Filtration and evaporation in vacuo furnished the crude product, which was purified by silica gel flash chromatography with gradient elution 5\%-10\% AcOEt-hexanes to give a sample of ester (+)-28a (70 mg) and an inseparable mixture of diastereoisomeric esters 28a/b (12.97 g, yield 97\% yield). (+)-28a: $R_{\mathrm{f}}=0.35$ (25\% AcOEt/hexanes). $[\alpha]_{D}^{20}=+23.72\left(c 1.0, \mathrm{CH}_{2} \mathrm{Cl}_{2}\right)$. FT-IR (thin film) $v\left(\mathrm{~cm}^{-1}\right): 2954,2932,2896,2857,1740,1717,1600,1587$, $1497,1472,1375,1240,1173,1150,1043,974,917,838,811,779,756,692,605,510 .{ }^{1} \mathrm{H}-\mathrm{NMR}\left(\mathrm{CDCl}_{3}\right.$, $600 \mathrm{MHz}) \delta$ (ppm): 0.08 (two s, $\left.6 \mathrm{H},\left(\mathrm{CH}_{3}\right)_{2} \mathrm{Si}\right), 0.89\left(\mathrm{~s}, 9 \mathrm{H},\left(\mathrm{CH}_{3}\right)_{3} \mathrm{C}-\mathrm{Si}\right), 1.00\left(\mathrm{~s}, 3 \mathrm{H},\left(-\mathrm{C}\left(\mathrm{CH}_{3}\right)\left(\mathrm{CH}_{2} \mathrm{OH}\right)_{2}\right)\right.$, $1.64\left(\mathrm{~m}, 3 \mathrm{H}\right.$, one of the cyclopentane $\mathrm{CH}_{2}-4$ group and $\alpha$-chain $\left.\mathrm{CH}_{2}-3\right), 1.68(\mathrm{~m}, 1 \mathrm{H}$, cyclopentane $\mathrm{CH}-1$ ), 1.95-2.16 (three s and two $\mathrm{m}, 16 \mathrm{H}$, four -COOC $\underline{\mathrm{H}}_{3}$ groups, $\alpha$-chain $\mathrm{CH}_{2}-4$ and $\alpha$-chain $\mathrm{CH}_{2}-7$ ), $2.28\left(\mathrm{t}, J=7.7 \mathrm{~Hz}, 2 \mathrm{H}, \alpha\right.$-chain $\left.\mathrm{CH}_{2}-2\right), 2.55-2.65\left(\mathrm{~m}, 2 \mathrm{H}\right.$, one proton of the cyclopentane $\mathrm{CH}_{2}-4$ group and cyclopentane $\mathrm{CH}-2), 3.83\left(\mathrm{dd}, J=9.4\right.$ and $5.2 \mathrm{~Hz}, 1 \mathrm{H}$, one of the $\omega$-chain $\mathrm{CH}_{2}-4$ group), 3.89 (dd, $J=9.4$ and $6.9 \mathrm{~Hz}, 1 \mathrm{H}$, one of the $\omega$-chain $\mathrm{CH}_{2}-4$ group), $3.99\left(\mathrm{~s}, 6 \mathrm{H},-\mathrm{OCH}_{2} \mathrm{C}\left(\mathrm{CH}_{3}\right)\left(\mathrm{CH}_{2} \mathrm{OH}\right)_{2}\right), 4.50(\mathrm{~m}$, $1 \mathrm{H}$, w-chain CH-3), 4.90 (m, 1H, cyclopentane CH-3), 5.09 (m, 1H, cyclopentane CH-5), 5.30-5.38 (m, $2 \mathrm{H}, \alpha$-chain $\mathrm{CH}-5$ and $\alpha$-chain $\mathrm{CH}-6), 5.62(\mathrm{dd}, J=8.3$ and $15.3 \mathrm{~Hz}, 1 \mathrm{H}, \omega$-chain $\mathrm{CH}-1), 5.67(\mathrm{dd}, J=5.6$ and $15.3 \mathrm{~Hz}, 1 \mathrm{H}, \omega$-chain $\mathrm{CH}-2), 6.87$ (m, 2H, aromatic $\mathrm{CH}-2$ and $\mathrm{CH}-6), 6.93$ (m, 1H, aromatic $\mathrm{CH}-4)$, $7.27(\mathrm{~m}, 2 \mathrm{H}$, aromatic $\mathrm{CH}-3$ and $\mathrm{CH}-5) .{ }^{13} \mathrm{C}-\mathrm{NMR}\left(150 \mathrm{MHz}, \mathrm{CDCl}_{3}\right) \delta(\mathrm{ppm}):-4.7\left(\mathrm{CH}_{3}-\mathrm{Si}_{)}\right),-4.6$ $\left(\mathrm{CH}_{3}-\mathrm{Si}\right), 17.0\left(-\mathrm{C}\left(\mathrm{CH}_{3}\right)\left(\mathrm{CH}_{2} \mathrm{OH}\right)_{2}\right), 18.3\left(\left(\mathrm{CH}_{3}\right)_{3} \underline{\mathrm{C}}-\mathrm{Si}\right), 20.7,21.0$ and $21.2\left(4 \mathrm{C}\right.$, four $-\mathrm{COOC} \mathrm{H}_{3}$ groups), 24.7 ( $\alpha$-chain C-3), 24.9 ( $\alpha$-chain C-7), 25.8 (3C, $\left.\left(\underline{\mathrm{CH}}_{3}\right)_{3} \mathrm{C}-\mathrm{Si}\right), 26.6$ ( $\alpha$-chain $\left.\mathrm{C}-4\right), 33.5$ ( $\alpha$-chain C-2), 38.2 $\left(-\mathrm{C}\left(\mathrm{CH}_{3}\right)\left(\mathrm{CH}_{2} \mathrm{OH}\right)_{2}\right), 39.0$ (cyclopentane C-4), 47.3 (cyclopentane C-1), 51.8 (cyclopentane C-2), 65.6 $\left(-\mathrm{OCH}_{2} \mathrm{C}\left(\mathrm{CH}_{3}\right)\left(\mathrm{CH}_{2} \mathrm{OH}\right)_{2}\right), 65.7\left(2 \mathrm{C},-\mathrm{OCH}_{2} \mathrm{C}\left(\mathrm{CH}_{3}\right)\left(\mathrm{CH}_{2} \mathrm{OH}\right)_{2}\right), 71.7$ ( $\omega$-chain C-3), 72.1 ( $\omega$-chain C-4), 74.3 (cyclopentane C-5), 77.8 (cyclopentane C-3), 114.4 (2C, aromatic C-2 and C-6), 120.9 (aromatic C-4), 128.0 ( $\alpha$-chain CH-6), 129.4 (2C, aromatic C-3 and C-5), 129.7 ( $\alpha$-chain CH-5), 131.4 ( $\omega$-chain C-1), 
133.2 ( $\omega$-chain C-2), 158.8 (aromatic C-1), 170.4, 170.6 and 170.7 (4C, four $-\mathrm{COOCH}_{3}$ groups). 173.1 $\left(-\mathrm{CH}_{2} \mathrm{COOCH}_{2}-\right.$ ). HRMS (ESI): calcd. for $\mathrm{C}_{41} \mathrm{H}_{62} \mathrm{O}_{12} \mathrm{NaSi}[\mathrm{M}+\mathrm{Na}]^{+}$797.3908; found 797.3898.

3.6.5. 2,2-Bis(acetoxymethyl)propyl (5Z)-7-\{(1R,2R,3R,5S)-3,5-Diacetoxy-2-[(1E,3R/3S)-4-phenoxy3-hydroxybut-1-enyl]cyclopentyl\}hept-5-enoate $(29 \mathbf{a} / \mathbf{b})$

Camphorosulfonic acid $(1.12 \mathrm{~g}, 4.81 \mathrm{mmol})$ was added to a solution of diastereoisomeric esters 28a/ $\mathbf{b}(11.3 \mathrm{~g}, 14.58 \mathrm{mmol})$ in a mixture of $\mathrm{MeOH}-\mathrm{CH}_{2} \mathrm{Cl}_{2}(1: 1,100 \mathrm{~mL})$. The resulting solution was stirred for $7 \mathrm{~h}$, whereupon $\mathrm{NaHCO}_{3}(0.47 \mathrm{~g})$ was added. After being stirred for $30 \mathrm{~min}$, the mixture was filtered through a Büchner funnel and the filtrate was concentrated under reduced pressure. The crude product was purified by silica gel flash chromatography with gradient elution $5 \%-40 \%$ AcOEt-hexanes to give a sample of alcohol (+)-29a (59 mg) and an inseparable mixture of diastereoisomeric alcohols 29a/b (6.94 g, 82\% yield). (+)-29a: $R_{\mathrm{f}}=0.37$ (50\% AcOEt/hexanes). $[\alpha]_{D}^{20}=+32.46$ (c 1.0, MeOH). FT-IR (thin film) $\vee\left(\mathrm{cm}^{-1}\right)$ : 3501, 2940, 1740, 1600, 1497, 1378, 1243, 1173, 1152, 1042, 975, 915, 814, 757, 693, 606, 512. ${ }^{1} \mathrm{H}-\mathrm{NMR}\left(\mathrm{CDCl}_{3}, 600 \mathrm{MHz}\right) \delta(\mathrm{ppm}): 1.00\left(\mathrm{~s}, 3 \mathrm{H},\left(-\mathrm{C}\left(\mathrm{CH}_{3}\right)\left(\mathrm{CH}_{2} \mathrm{OH}\right)_{2}\right), 1.60-1.74(\mathrm{~m}, 4 \mathrm{H}\right.$, one of the cyclopentane $\mathrm{CH}_{2}-4$ group, cyclopentane $\mathrm{CH}-1, \alpha$-chain $\mathrm{CH}_{2}-3$ ), 1.95-2.10 (three $\mathrm{s}$ and two $\mathrm{m}$, $14 \mathrm{H}$, four - $\mathrm{COOC} \underline{\mathrm{H}}_{3}$ groups and $\alpha$-chain $\left.\mathrm{CH}_{2}-4\right), 2.14\left(\mathrm{~m}, 2 \mathrm{H}, \alpha\right.$-chain $\left.\mathrm{CH}_{2}-7\right), 2.30(\mathrm{t}, J=7.7 \mathrm{~Hz}, 2 \mathrm{H}$, $\alpha$-chain $\left.\mathrm{CH}_{2}-2\right), 2.55\left(\mathrm{~m}, 1 \mathrm{H}\right.$, one of the cyclopentane $\mathrm{CH}_{2}-4$ group), $2.62(\mathrm{~m}, 1 \mathrm{H}$, cyclopentane $\mathrm{CH}-2)$, $3.91\left(\mathrm{dd}, J=7.2\right.$ and $9.0 \mathrm{~Hz}, 1 \mathrm{H}$, one of the $\alpha$-chain $\left.\mathrm{CH}_{2}-4\right), 3.99\left(\mathrm{~m}, 7 \mathrm{H},-\mathrm{OCH}_{2} \mathrm{C}\left(\mathrm{CH}_{3}\right)\left(\mathrm{CH}_{2} \mathrm{OH}\right)_{2}\right.$ and one of the $\omega$-chain $\mathrm{CH}_{2}-4$ group), $4.54(\mathrm{~m}, 1 \mathrm{H}, \omega$-chain $\mathrm{CH}-3), 4.94(\mathrm{~m}, 1 \mathrm{H}$, cyclopentane $\mathrm{CH}-3), 5.11(\mathrm{~m}$, $1 \mathrm{H}$, cyclopentane $\mathrm{CH}-5), 5.30-5.38(\mathrm{~m}, 2 \mathrm{H}, \alpha$-chain $\mathrm{CH}-5$ and $\alpha$-chain $\mathrm{CH}-6), 5.71(\mathrm{dd}, J=5.4$ and 15.6 $\mathrm{Hz}, 1 \mathrm{H}$, $\omega$-chain $\mathrm{CH}-1), 5.74(\mathrm{dd}, J=7.2$ and $15.6 \mathrm{~Hz}, 1 \mathrm{H}, \omega$-chain $\mathrm{CH}-2), 6.92(\mathrm{~m}, 2 \mathrm{H}$, aromatic $\mathrm{CH}-2$ and $\mathrm{CH}-6), 6.98(\mathrm{~m}, 1 \mathrm{H}$, aromatic $\mathrm{CH}-4), 7.29(\mathrm{~m}, 2 \mathrm{H}$, aromatic $\mathrm{CH}-3$ and $\mathrm{CH}-5) .{ }^{13} \mathrm{C}-\mathrm{NMR}(150 \mathrm{MHz}$, $\left.\mathrm{CDCl}_{3}\right) \delta(\mathrm{ppm}): 17.0\left(-\mathrm{C}\left(\mathrm{CH}_{3}\right)\left(\mathrm{CH}_{2} \mathrm{OH}\right)_{2}\right), 20.7,21.1$ and $21.2\left(4 \mathrm{C}\right.$, four $-\mathrm{COOC} \mathrm{H}_{3}$ groups), 24.6 ( $\alpha$-chain $\mathrm{C}-3), 24.8(\alpha$-chain C-7), 26.6 ( $\alpha$-chain $\mathrm{C}-4), 33.5(\alpha$-chain $\mathrm{C}-2), 38.2\left(-\mathrm{C}\left(\mathrm{CH}_{3}\right)\left(\mathrm{CH}_{2} \mathrm{OH}\right)_{2}\right), 39.0$ (cyclopentane C-4), 47.3 (cyclopentane C-1), 52.0 (cyclopentane C-2), $65.6\left(-\mathrm{OCH}_{2} \mathrm{C}\left(\mathrm{CH}_{3}\right)\left(\mathrm{CH}_{2} \mathrm{OH}\right)_{2}\right)$, $65.7\left(2 \mathrm{C},-\mathrm{OCH}_{2} \mathrm{C}\left(\mathrm{CH}_{3}\right)\left(\mathrm{CH}_{2} \mathrm{OH}\right)_{2}\right), 70.5$ ( $\omega$-chain $\left.\mathrm{C}-3\right), 71.7$ ( $\omega$-chain $\left.\mathrm{C}-4\right), 74.3$ (cyclopentane $\left.\mathrm{C}-5\right)$, 77.8 (cyclopentane $\mathrm{C}-3), 114.6$ (2C, aromatic C-2 and C-6), 121.2 (aromatic C-4), 128.1 ( $\alpha$-chain CH-6), 129.5 (2C, aromatic C-3 and C-5), 129.8 ( $\alpha$-chain $\mathrm{CH}-5), 131.1$ ( $\omega$-chain $\mathrm{C}-2), 132.6$ ( $\omega$-chain $\mathrm{C}-1), 158.5$ (aromatic C-1), 170.4, 170.6 and 170.7 (4C, four $-\mathrm{COOCH}_{3}$ groups). $173.2\left(-\mathrm{CH}_{2} \mathrm{COOCH}_{2}-\right)$. HRMS (ESI): calcd. for $\mathrm{C}_{35} \mathrm{H}_{48} \mathrm{O}_{12} \mathrm{Na}[\mathrm{M}+\mathrm{Na}]^{+}$683.3043; found 683.3040.

3.6.6. 2,2-Bis(acetoxymethyl)propyl (5Z)-7-\{(1R,2R,3R,5S)-3,5-Diacetoxy-2-[(1E)-4-(phenoxy)-3-oxobut-1-enyl]cyclopentyl\}hept-5-enoate (30)

Dess-Martin periodinane $(4.48 \mathrm{~g}, 10.56 \mathrm{mmol})$ was added portionwise to a suspension of diastereoisomeric alcohols $\mathbf{2 9 a} / \mathbf{b}(5.8 \mathrm{~g}, 8.8 \mathrm{mmol})$ and dry $\mathrm{NaHCO}_{3}(2.22 \mathrm{~g}, 26.4 \mathrm{mmol})$ in anhydrous $\mathrm{CH}_{2} \mathrm{Cl}_{2}(50 \mathrm{~mL}$ ). After being stirred for $1 \mathrm{~h}$ at room temperature, TLC analysis (AcOEt/hexanes, 1:1) indicated disappearance of the starting alcohols $29 \mathbf{a} / \mathbf{b}$. Saturated aqueous $\mathrm{NaHCO}_{3}(100 \mathrm{~mL})$ and $\mathrm{Na}_{2} \mathrm{SO}_{3}(8.87 \mathrm{~g}, 70.4 \mathrm{mmol})$ were then added simultaneously and the mixture was stirred at room temperature for $30 \mathrm{~min}$ The resulting layers were separated and the aqueous phase was extracted with $\mathrm{CH}_{2} \mathrm{Cl}_{2}(3 \times 50 \mathrm{~mL})$. The combined extracts were washed with water brine $(100 \mathrm{~mL})$ and dried over $\mathrm{Na}_{2} \mathrm{SO}_{4}$. Filtration and evaporation in vacuo furnished the crude product as a light yellow oil, which was purified by flash column chromatography (silica gel, $2 \%-20 \%$ AcOEt/hexanes) to give the ketone 30 (5.76 g, 99\% yield) as a colorless oil. $R_{\mathrm{f}}=0.54$ (50\% AcOEt/hexanes). $[\alpha]_{D}^{20}=+40.67$ (c 1.0, $\mathrm{CH}_{2} \mathrm{Cl}_{2}$ ). FT-IR (thin film) $v\left(\mathrm{~cm}^{-1}\right)$ : 2944, 1740, 1697, 1626, 1600, 1589, 1496, 1474, 1435, 1376, 1239, 1174, 1043, 984, 917, 785, 757, 693, 645, 606, 509. ${ }^{1} \mathrm{H}-\mathrm{NMR}\left(\mathrm{CDCl}_{3}, 600 \mathrm{MHz}\right) \delta(\mathrm{ppm}): 1.01$ (s, $\left.3 \mathrm{H},-\mathrm{C}\left(\mathrm{CH}_{3}\right)\left(\mathrm{CH}_{2} \mathrm{OH}\right)_{2}\right), 1.64\left(\mathrm{~m}, 2 \mathrm{H}, \alpha\right.$-chain $\left.\mathrm{CH}_{2}-3\right), 1.73(\mathrm{ddd}, J=1.3,4.2$ and $15.8 \mathrm{~Hz}, 1 \mathrm{H}$, one of the cyclopentane $\mathrm{CH}_{2}-4$ group), $1.84(\mathrm{~m}, 1 \mathrm{H}$, cyclopentane $\mathrm{CH}-1), 1.92-2.10$ (three $\mathrm{s}$ and two $\mathrm{m}$, $15 \mathrm{H}$, four - $\mathrm{COOCH}_{3}$ groups, $\alpha$-chain $\mathrm{CH}_{2}-4$ and one of the $\alpha$-chain $\mathrm{CH}_{2}-7$ group), $2.15(\mathrm{~m}, 1 \mathrm{H}$, one of the $\alpha$-chain $\mathrm{CH}_{2}-7$ group), $2.29\left(\mathrm{t}, J=7.6 \mathrm{~Hz}, 2 \mathrm{H}, \alpha\right.$-chain $\mathrm{CH}_{2}-2$ group), 2.58 (ddd, $J=5.6,9.1$ and $15.8 \mathrm{~Hz}, 1 \mathrm{H}$, one of the cyclopentane $\mathrm{CH}_{2}-4$ group), $2.76(\mathrm{~m}, 1 \mathrm{H}$, cyclopentane $\mathrm{CH}-2$ group), 3.99 (m, 
$\left.6 \mathrm{H},-\mathrm{OC} \underline{\mathrm{H}}_{2} \mathrm{C}\left(\mathrm{CH}_{3}\right)\left(\mathrm{CH}_{2} \mathrm{OH}\right)_{2}\right), 4.72\left(\right.$ two d, $J=16.4 \mathrm{~Hz}, \omega$-chain $\left.\mathrm{CH}_{2}-4\right), 4.98$ (ddd, $J=4.2,7.4$ and $11.7 \mathrm{~Hz}, 1 \mathrm{H}$, cyclopentane $\mathrm{CH}-3), 5.12(\mathrm{~m}, 1 \mathrm{H}$, cyclopentane $\mathrm{CH}-5), 5.29(\mathrm{~m}, 1 \mathrm{H}, \alpha$-chain CH-6), 5.34 $(\mathrm{m}, 1 \mathrm{H}, \alpha$-chain $\mathrm{CH}-5), 6.51(\mathrm{dd}, J=0.8$ and $15.7 \mathrm{~Hz}, 1 \mathrm{H}, \omega$-chain $\mathrm{CH}-2), 6.90(\mathrm{~m}, 2 \mathrm{H}$, aromatic $\mathrm{CH}-2$ and $\mathrm{CH}-6), 6.92(\mathrm{dd}, J=9.1$ and $15.7 \mathrm{~Hz}, 1 \mathrm{H}$, $\omega$-chain $\mathrm{CH}-1), 6.99(\mathrm{~m}, 1 \mathrm{H}$, aromatic $\mathrm{CH}-4), 7.29(\mathrm{~m}$, $2 \mathrm{H}$, aromatic $\mathrm{CH}-3$ and $\mathrm{CH}-5) .{ }^{13} \mathrm{C}-\mathrm{NMR}\left(150 \mathrm{MHz}, \mathrm{CDCl}_{3}\right) \delta(\mathrm{ppm}): 17.0\left(-\mathrm{C}\left(\mathrm{CH}_{3}\right)\left(\mathrm{CH}_{2} \mathrm{OH}\right)_{2}\right), 20.7$, 21.1 and 21.2 (4C, four - $\mathrm{COOC}_{3}$ groups), 24.6 ( $\alpha$-chain $\mathrm{C}-3$ ), 25.0 ( $\alpha$-chain $\left.\mathrm{C}-7\right), 26.6$ ( $\alpha$-chain $\mathrm{C}-4$ ), 33.5 ( $\alpha$-chain $\mathrm{C}-2), 38.2\left(-\mathrm{C}\left(\mathrm{CH}_{3}\right)\left(\mathrm{CH}_{2} \mathrm{OH}\right)_{2}\right), 39.1$ (cyclopentane $\left.\mathrm{C}-4\right), 47.7$ (cyclopentane $\left.\mathrm{C}-1\right), 52.4$ (cyclopentane C-2), $65.6\left(-\mathrm{OCH}_{2} \mathrm{C}\left(\mathrm{CH}_{3}\right)\left(\mathrm{CH}_{2} \mathrm{OH}\right)_{2}\right), 65.7\left(2 \mathrm{C},-\mathrm{OCH}_{2} \mathrm{C}\left(\mathrm{CH}_{3}\right)\left(\mathrm{CH}_{2} \mathrm{OH}\right)_{2}\right), 72.0$ (w-chain C-4), 74.3 (cylopentane C-5), 77.2 (cyclopentane C-3), 114.6 (2C, aromatic C-2 and C-6), 121.7 (aromatic C-4), 127.2 ( $\omega$-chain $\mathrm{CH}-2), 127.4$ ( $\alpha$-chain $\mathrm{CH}-6), 129.6$ (2C, aromatic C-3 and C-5), 130.3 ( $\alpha$-chain $\mathrm{CH}-5), 147.7$ ( $\omega$-chain $\mathrm{C}-1), 157.8$ (aromatic $\mathrm{C}-1), 170.2,170.4$ and 170.7 (4C, four - $\mathrm{COOCH}_{3}$ groups), $173.1\left(-\mathrm{CH}_{2} \mathrm{COOCH}_{2}\right), 195.5$ ( $\omega$-chain C-3). HRMS (ESI): calcd. for $\mathrm{C}_{35} \mathrm{H}_{46} \mathrm{O}_{12} \mathrm{Na}[\mathrm{M}+\mathrm{Na}]^{+}$681.2887; found 681.2877 .

3.6.7. 2,2-Bis(acetoxymethyl)propyl (5Z)-7-\{(1R,2R,3R,5S)-3,5-diacetoxy-2-[(1E)-3,3-difluoro-4-(phenoxy)-but-1-enyl]cyclopentyl\}hept-5-enoate (31)

Deoxo-Fluor ( $39.1 \mathrm{~mL}, 91.2 \mathrm{mmol}, 50 \%$ in THF) was added dropwise to a stirred solution of ketone 30 (5.0 g, $7.6 \mathrm{mmol})$ in $\mathrm{CH}_{2} \mathrm{Cl}_{2}(60 \mathrm{~mL})$ at $0{ }^{\circ} \mathrm{C}$ under an argon atmosphere. The resulting mixture was refluxed for $24 \mathrm{~h}$, cooled to $0-5{ }^{\circ} \mathrm{C}$, whereupon saturated aqueous solution of $\mathrm{NaHCO}_{3}(200 \mathrm{~mL})$ was added dropwise. After being stirred for $30 \mathrm{~min}$ at room temperature, the layers were separated and the aqueous phase was extracted with $\mathrm{CH}_{2} \mathrm{Cl}_{2}(3 \times 50 \mathrm{~mL})$. The combined extracts were washed with brine $(100 \mathrm{~mL})$ and dried over $\mathrm{Na}_{2} \mathrm{SO}_{4}$. Filtration and evaporation in vacuo furnished the crude product as a light yellow oil, which was purified by flash column chromatography (silica gel, $5 \%-20 \%$ AcOEt/hexanes) to give the difluoro derivative 31 ( $4.03 \mathrm{~g}, 78 \%$ yield) as a colorless oil. $R_{\mathrm{f}}=0.64$ (50\% AcOEt/hexanes). $[\alpha]_{D}^{20}=+27.75(c 1.0, \mathrm{MeOH})$. FT-IR (thin film) $v\left(\mathrm{~cm}^{-1}\right): 2945,1739,1599,1496$, 1378, 1239, 1159, 1046, 977, 849, 757, 693, 606, 509. ${ }^{1} \mathrm{H}-\mathrm{NMR}\left(\mathrm{CDCl}_{3}, 600 \mathrm{MHz}\right) \delta$ (ppm): 1.00 (s, 3H, $\left.-\mathrm{C}\left(\mathrm{C}_{3}\right)\left(\mathrm{CH}_{2} \mathrm{OH}\right)_{2}\right), 1.64\left(\mathrm{~m}, 2 \mathrm{H}, \alpha\right.$-chain $\left.\mathrm{CH}_{2}-3\right), 1.70(\mathrm{ddd}, J=1.3,4.5$ and $15.8 \mathrm{~Hz}, 1 \mathrm{H}$, one proton of the cyclopentane $\mathrm{CH}_{2}-4$ group), $1.77(\mathrm{~m}, 1 \mathrm{H}$, cyclopentane $\mathrm{CH}-1), 1.95-2.10$ (three $\mathrm{s}$ and two $\mathrm{m}$, $14 \mathrm{H}$, four - $\mathrm{COOC}_{3}$ groups and $\alpha$-chain $\left.\mathrm{CH}_{2}-4\right), 2.14\left(\mathrm{~m}, 2 \mathrm{H}, \alpha\right.$-chain $\left.\mathrm{CH}_{2}-7\right), 2.28(\mathrm{t}, J=7.6 \mathrm{~Hz}, 2 \mathrm{H}$, $\alpha$-chain $\left.\mathrm{CH}_{2}-2\right), 2.58\left(\mathrm{ddd}, J=5.8,9.0\right.$ and $15.8 \mathrm{~Hz}, 1 \mathrm{H}$, one proton of the cyclopentane $\left.\mathrm{CH}_{2}-4\right), 2.68(\mathrm{~m}$, $1 \mathrm{H}$, cyclopentane $\mathrm{CH}-2), 4.00\left(\mathrm{~m}, 6 \mathrm{H},-\mathrm{OCH}_{2} \mathrm{C}\left(\mathrm{CH}_{3}\right)\left(\mathrm{CH}_{2} \mathrm{OH}\right)_{2}\right), 4.19\left(\mathrm{~m}, 2 \mathrm{H}, \omega\right.$-chain $\left.\mathrm{CH}_{2}-4\right), 4.95$ (ddd, $J=4.5,7.7$ and $11.9 \mathrm{~Hz}, 1 \mathrm{H}$, cyclopentane $\mathrm{CH}-3), 5.12(\mathrm{~m}, 1 \mathrm{H}$, cyclopentane $\mathrm{CH}-5), 5.32-5.40$ $(\mathrm{m}, 2 \mathrm{H}, \alpha$-chain $\mathrm{CH}-5$ and $\alpha$-chain $\mathrm{CH}-6), 5.84(\mathrm{~m}, 1 \mathrm{H}, \omega$-chain $\mathrm{CH}-2), 6.11(\mathrm{~m}, 1 \mathrm{H}, \omega$-chain $\mathrm{CH}-1)$, $6.91(\mathrm{~m}, 2 \mathrm{H}$, aromatic $\mathrm{CH}-2$ and $\mathrm{CH}-6), 7.00(\mathrm{~m}, 1 \mathrm{H}$, aromatic $\mathrm{CH}-4), 7.30(\mathrm{~m}, 2 \mathrm{H}$, aromatic $\mathrm{CH}-3$ and CH-5). ${ }^{13} \mathrm{C}-\mathrm{NMR}\left(150 \mathrm{MHz}, \mathrm{CDCl}_{3}\right) \delta$ (ppm): $17.0\left(-\mathrm{C}\left(\mathrm{CH}_{3}\right)\left(\mathrm{CH}_{2} \mathrm{OH}\right)_{2}\right), 20.8,21.1$ and $21.2(4 \mathrm{C}$, four -COOCH${ }_{3}$ groups), 24.6 ( $\alpha$-chain C-3), 24.8 ( $\alpha$-chain C-7), 26.6 ( $\alpha$-chain C-4), 33.5 ( $\alpha$-chain $\mathrm{C}-2$ ), 38.2 $\left(-\mathrm{C}\left(\mathrm{CH}_{3}\right)\left(\mathrm{CH}_{2} \mathrm{OH}\right)_{2}\right), 39.0$ (cyclopentane $\left.\mathrm{C}-4\right), 47.4$ (cyclopentane $\left.\mathrm{C}-1\right), 51.8$ (cyclopentane $\left.\mathrm{C}-2\right), 65.6$ $\left(-\mathrm{OCH}_{2} \mathrm{C}\left(\mathrm{CH}_{3}\right)\left(\mathrm{CH}_{2} \mathrm{OH}\right)_{2}\right), 65.8\left(2 \mathrm{C},-\mathrm{OCH}_{2} \mathrm{C}\left(\mathrm{CH}_{3}\right)\left(\mathrm{CH}_{2} \mathrm{OH}\right)_{2}\right), 69.5\left({ }^{2}{ }^{\mathrm{C}-\mathrm{F}}=35.0 \mathrm{~Hz}, \omega\right.$-chain C-4 $), 74.2$ (cyclopentane C-5), 77.2 (cyclopentane C-3), $114.7\left(2 \mathrm{C}\right.$, aromatic C-2 and C-6), $118.0\left({ }^{1} J_{\mathrm{C}-\mathrm{F}}=240.5 \mathrm{~Hz}\right.$, $\omega$-chain C-3), 121.8 (aromatic C-4), $125.2\left({ }^{2} J_{\mathrm{C}-\mathrm{F}}=25.0 \mathrm{~Hz}, \omega\right.$-chain $\left.\mathrm{C}-2\right), 127.6(\alpha$-chain $\mathrm{CH}-6), 129.6$ (2C, aromatic C-3 and C-5), 130.1 ( $\alpha$-chain CH-5), $136.8\left({ }^{3} J_{\mathrm{C}-\mathrm{F}}=8.8 \mathrm{~Hz}, \omega\right.$-chain C-1), 157.9 (aromatic $\mathrm{C}-1), 170.3,170.6$ and 170.8 (4C, four $-\mathrm{COOCH}_{3}$ groups), $173.1\left(-\mathrm{CH}_{2} \mathrm{COOCH}_{2}\right)$. HRMS (ESI): calcd. for $\mathrm{C}_{35} \mathrm{H}_{46} \mathrm{O}_{11} \mathrm{NaF}_{2}[\mathrm{M}+\mathrm{Na}]^{+}$703.2906; found 703.2900.

3.6.8. Methyl (5Z)-7-\{(1R,2R,3R,5S)-2-[(1E)-3,3-difluoro-4-(phenoxy)but-1-enyl]-3,5-dihydroxycyclopentyl\}hept-5-enoate (32)

$\mathrm{K}_{2} \mathrm{CO}_{3}(0.46 \mathrm{~g}, 3.3 \mathrm{mmol})$ was added to a solution of ester $31(0.75 \mathrm{~g}, 1.1 \mathrm{mmol})$ in $\mathrm{MeOH}(25 \mathrm{~mL})$. The resulting suspension was stirred for $24 \mathrm{~h}$ at room temperature and then concentrated under reduced pressure. The residue was diluted with $\mathrm{H}_{2} \mathrm{O}(50 \mathrm{~mL})$ and the product was extracted with AcOEt $(3 \times 25 \mathrm{~mL})$. The combined extracts were washed with brine $(100 \mathrm{~mL})$ and dried over $\mathrm{Na}_{2} \mathrm{SO}_{4}$. 
Filtration and evaporation in vacuo furnished the crude product as a light yellow oil, which was purified by flash column chromatography (silica gel, $10 \%-40 \% \mathrm{AcOEt} /$ hexanes) to give the methyl ester 32 ( $0.35 \mathrm{~g}, 76 \%$ yield) as a colorless oil. $R_{\mathrm{f}}=0.48\left(75 \% \mathrm{AcOEt} /\right.$ hexanes). $[\alpha]_{D}^{20}=+23.97$ (c 1.0, $\mathrm{MeOH})$. FT-IR (thin film) $v\left(\mathrm{~cm}^{-1}\right): 3412,3009,2935,1733,1676,1599,1497,1456,1438,1303,1250$, 1155, 1055, 975, 935, 848, 756, 692, 509. ${ }^{1} \mathrm{H}-\mathrm{NMR}\left(\mathrm{CDCl}_{3}, 600 \mathrm{MHz}\right) \delta$ (ppm): $1.62(\mathrm{~m}, 1 \mathrm{H}$, cyclopentane $\mathrm{CH}-1), 1.68\left(\mathrm{~m}, 2 \mathrm{H}, \alpha\right.$-chain $\left.\mathrm{CH}_{2}-3\right), 1.85\left(\mathrm{~m}, 1 \mathrm{H}\right.$, one proton of the cyclopentane $\mathrm{CH}_{2}-4$ group), 2.07 (m, $1 \mathrm{H}$, one of the $\alpha$-chain $\mathrm{CH}_{2}-4$ group), $2.10-2.18\left(\mathrm{~m}, 3 \mathrm{H}\right.$, one of the $\alpha$-chain $\mathrm{CH}_{2}-4$ group, one of the $\alpha$-chain $\mathrm{CH}_{2}-7$ group and one of the cyclopentane $\mathrm{CH}_{2}-4$ group), 2.18-2.26 (br s, 2H, two -OH), 2.27-2.36 (m, 3H, one of the $\alpha$-chain $\mathrm{CH}_{2}-7$ group and $\alpha$-chain $\left.\mathrm{CH}_{2}-2\right), 2.47(\mathrm{~m}, 1 \mathrm{H}$, cyclopentane $\mathrm{CH}-2), 3.66\left(\mathrm{~s}, 3 \mathrm{H},-\mathrm{COOC} \mathrm{H}_{3}\right), 4.03(\mathrm{~m}, 1 \mathrm{H}$, cyclopentane $\mathrm{CH}-3), 4.17-4.23(\mathrm{~m}, 2 \mathrm{H}$, cyclopentane $\mathrm{CH}-5$ and $\alpha$-chain $\left.\mathrm{CH}_{2}-4\right), 5.33-5.42(\mathrm{~m}, 2 \mathrm{H}, \alpha$-chain $\mathrm{CH}-5$ and $\alpha$-chain $\mathrm{CH}-6), 5.80(\mathrm{~m}, 1 \mathrm{H}, \omega$-chain $\mathrm{CH}-2)$, $6.11(\mathrm{~m}, 1 \mathrm{H}, \omega$-chain $\mathrm{CH}-1), 6.91(\mathrm{~m}, 2 \mathrm{H}$, aromatic $\mathrm{CH}-2$ and $\mathrm{CH}-6), 7.00(\mathrm{~m}, 1 \mathrm{H}$, aromatic $\mathrm{CH}-4), 7.30$ (m, 2H, aromatic CH-3 and CH-5). ${ }^{13} \mathrm{C}-\mathrm{NMR}\left(150 \mathrm{MHz}, \mathrm{CDCl}_{3}\right) \delta$ (ppm): 24.7 ( $\alpha$-chain C-3), 25.7 ( $\alpha$-chain C-7), 26.6 ( $\alpha$-chain C-4), 33.3 ( $\alpha$-chain C-2), 43.0 (cyclopentane $C-4), 50.5$ (cyclopentane $C-1)$, $51.6\left(-\mathrm{COOCH}_{3}\right), 55.8$ (cyclopentane C-2), $69.5\left({ }^{2} J_{\mathrm{C}-\mathrm{F}}=35.0 \mathrm{~Hz}\right.$, w-chain C-4), 73.3 (cyclopentane C-5), 78.0 (cyclopentane C-3), $114.7\left(2 \mathrm{C}\right.$, aromatic C-2 and C-6), $118.1\left({ }^{1} J_{\mathrm{C}-\mathrm{F}}=241.0 \mathrm{~Hz}\right.$, $\omega$-chain C-3), 121.8 (aromatic C-4), $123.6\left({ }^{2} J_{\mathrm{C}-\mathrm{F}}=24.9 \mathrm{~Hz}\right.$, $\omega$-chain C-2), 128.6 ( $\alpha$-chain $\left.\mathrm{CH}-6\right), 129.6$ (2C, aromatic C-3 and C-5), 130.0 ( $\alpha$-chain CH-5), $138.6\left({ }^{3} J_{\mathrm{C}-\mathrm{F}}=9.1 \mathrm{~Hz}\right.$, $\omega$-chain $\left.\mathrm{C}-1\right), 157.9$ (aromatic C-1), $174.3(\mathrm{C}=\mathrm{O})$. HRMS (ESI): calcd. for $\mathrm{C}_{23} \mathrm{H}_{30} \mathrm{O}_{5} \mathrm{NaF}_{2}[\mathrm{M}+\mathrm{Na}]^{+}$447.1959; found 447.1960.

3.6.9. (5Z)-7-\{(1R,2R,3R,5S)-2-[(1E)-3,3-difluoro-4-(phenoxy)but-1-enyl]-3,5-dihydroxycyclopentyl\}hept-5-enoic acid (6)

$\mathrm{LiOH} \cdot \mathrm{H}_{2} \mathrm{O}(1.4 \mathrm{~g}, 33.36 \mathrm{mmol})$ was added in one portion to a solution of ester $31(2.84 \mathrm{~g}, 4.17 \mathrm{mmol})$ in $\mathrm{MeOH}(50 \mathrm{~mL})$. The resulting suspension was stirred overnight resulting in disappearance of the starting material 31 (TLC, $\mathrm{MeOH} / \mathrm{AcOEt} 1: 6)$. After cooling and evaporating the solvent, the residual solid was dissolved in water $(150 \mathrm{~mL})$ and washed with $\mathrm{Et}_{2} \mathrm{O}(25 \mathrm{~mL})$ to remove organic impurities. The water layer was acidified with citric acid to $\mathrm{pH} 4-5$ and the product was extracted with AcOEt $(3 \times 50 \mathrm{~mL})$. The combined organic extracts were dried over anhydrous $\mathrm{Na}_{2} \mathrm{SO}_{4}$, filtered and evaporated in vacuo to afford the crude acid. Purification by silica gel flash chromatography with gradient elution $10 \%-50 \% \mathrm{MeOH} / \mathrm{AcOEt}$ afforded the pure tafluprost acid (6) (1.69 g, $98 \%$ yield) as a thick pale yellow oil. $R_{\mathrm{f}}=0.49(15 \% \mathrm{MeOH} / \mathrm{AcOEt}) .[\alpha]_{D}^{20}=+17.98(c$ 1.0, MeOH). FT-IR (thin film) $v\left(\mathrm{~cm}^{-1}\right)$ : 3370, 2933, 1709, 1599, 1497, 1457, 1406, 1302, 1249, 1155, 1055, 974, 934, 849, 755, 692, 509. ${ }^{1} \mathrm{H}-\mathrm{NMR}\left(\mathrm{CDCl}_{3}, 600 \mathrm{MHz}\right) \delta(\mathrm{ppm}): 1.59(\mathrm{~m}, 1 \mathrm{H}$, cyclopentane $\mathrm{CH}-1), 1.66\left(\mathrm{~m}, 2 \mathrm{H}, \alpha\right.$-chain $\left.\mathrm{CH}_{2}-3\right)$, $1.84\left(\mathrm{~m}, 1 \mathrm{H}\right.$, one of the cyclopentane $\left.\mathrm{CH}_{2}-4\right), 2.00-2.20\left(\mathrm{~m}, 3 \mathrm{H}\right.$, one of the $\alpha$-chain $\mathrm{CH}_{2}-4$, one of the $\alpha$-chain $\mathrm{CH}_{2}-7$ and one of the cyclopentane $\mathrm{CH}_{2}-4$ group), $2.28-2.36\left(\mathrm{~m}, 3 \mathrm{H}\right.$, one of the $\alpha$-chain $\mathrm{CH}_{2}-7$ and $\alpha$-chain $\left.\mathrm{CH}_{2}-2\right), 2.47(\mathrm{~m}, 1 \mathrm{H}$, cyclopentane $\mathrm{CH}-2), 4.03(\mathrm{~m}, 1 \mathrm{H}$, cyclopentane $\mathrm{CH}-3), 4.17-4.22(\mathrm{~m}$, $3 \mathrm{H}$, cyclopentane $\mathrm{CH}-5$ and $\omega$-chain $\left.\mathrm{CH}_{2}-4\right), 5.33-5.42(\mathrm{~m}, 2 \mathrm{H}, \alpha$-chain $\mathrm{CH}-5$ and $\alpha$-chain $\mathrm{CH}-6), 5.80$ (m, 1H, $\omega$-chain CH-2), $6.10(\mathrm{~m}, 1 \mathrm{H}, \omega$-chain $\mathrm{CH}-1), 6.91(\mathrm{~m}, 2 \mathrm{H}$, aromatic $\mathrm{CH}-2$ and $\mathrm{CH}-6), 6.99(\mathrm{~m}$, $1 \mathrm{H}$, aromatic $\mathrm{CH}-4), 7.29(\mathrm{~m}, 2 \mathrm{H}$, aromatic $\mathrm{CH}-3$ and $\mathrm{CH}-5) .{ }^{13} \mathrm{C}-\mathrm{NMR}\left(150 \mathrm{MHz}, \mathrm{CDCl}_{3}\right) \delta$ (ppm): 24.5 ( $\alpha$-chain C-3), 25.7 ( $\alpha$-chain C-7), 26.4 ( $\alpha$-chain C-4), 33.2 ( $\alpha$-chain C-2), 42.8 (cyclopentane C-4), 50.4 (cyclopentane C-1), 55.5 (cyclopentane C-2), $69.5\left({ }^{2} J_{\mathrm{C}-\mathrm{F}}=34.7 \mathrm{~Hz}, \omega\right.$-chain C-4), 73.4 (cyclopentane C-5), 77.8 (cyclopentane C-3), $114.8\left(2 \mathrm{C}\right.$, aromatic C-2 and C-6), $118.2\left({ }^{1} \mathrm{~J}_{\mathrm{C}-\mathrm{F}}=240.0 \mathrm{~Hz}\right.$, $\omega$-chain C-3), 121.8 (aromatic C-4), $123.7\left({ }^{2} J_{\mathrm{C}-\mathrm{F}}=25.0 \mathrm{~Hz}, \omega\right.$-chain C-2), 128.8 ( $\alpha$-chain CH-6), $129.6(2 \mathrm{C}$, aromatic $\mathrm{C}-3$ and C-5), 129.9 ( $\alpha$-chain CH-5), $138.6\left({ }^{3} J_{\mathrm{C}-\mathrm{F}}=8.7 \mathrm{~Hz}\right.$, $\omega$-chain C-1), 158.0 (aromatic C-1), $178.8(\mathrm{C}=\mathrm{O})$. HRMS (ESI): calcd. for $\mathrm{C}_{22} \mathrm{H}_{28} \mathrm{O}_{5} \mathrm{NaF}_{2}[\mathrm{M}+\mathrm{Na}]^{+} 433.1803$; found 433.1801 .

3.6.10. Isopropyl (5Z)-7-\{(1R,2R,3R,5S)-2-[(1E)-3,3-difluoro-4-(phenoxy)but-1-enyl]-3,5-dihydroxycyclopentyl\}hept-5-enoate (5)

DBU (3.4 mL, $22.82 \mathrm{mmol})$ was added dropwise to a stirred solution of acid 6 (1.34 g, $3.26 \mathrm{mmol})$ in anhydrous $\mathrm{Me}_{2} \mathrm{CO}(20 \mathrm{~mL})$ at $0^{\circ} \mathrm{C}$ under an argon atmosphere. The mixture was allowed to warm to 
room temperature, whereupon 2-iodopropane $(2.3 \mathrm{~mL}, 22.82 \mathrm{mmol})$ was added dropwise. The resulting solution was stirred for $21 \mathrm{~h}$ resulting in disappearance of the starting acid 6 (TLC, MeOH/ AcOEt 1:6). The reaction was quenched with AcOEt $(100 \mathrm{~mL})$. The resulting white solid was filtered off and washed with AcOEt $(3 \times 15 \mathrm{~mL})$. The filtrate and washings were combined and acidified with $3 \%$ citric acid solution to $\mathrm{pH} 5-6$. The resulting layers were separated and the aqueous phase was extracted with AcOEt $(3 \times 15 \mathrm{~mL})$. The combined extracts were washed with saturated $\mathrm{NaHCO}_{3}(100 \mathrm{~mL})$, brine $(100 \mathrm{~mL})$ and dried over anhydrous $\mathrm{Na}_{2} \mathrm{SO}_{4}$. Filtration and evaporation in vacuo furnished the crude product, which was purified by silica gel flash chromatography with gradient elution $10 \%-45 \%$ AcOEt/hexanes to afford the title compound 5 (1.23 g, 83\% yield) as a pale yellow oil. This sample was further purified by preparative HPLC on silica gel to give pharmaceutical grade tafluprost (5) as a thick colorless oil. $[\alpha]_{D}^{20}=+22.46(c 1.0, \mathrm{MeOH})$. Lit. $[\alpha]_{D}^{23}=+21.6\left(c 1.0, \mathrm{CHCl}_{3}\right)[45] . R_{\mathrm{f}}=0.48$ (75\% AcOEt/hexanes). FT-IR (thin film) v $\left(\mathrm{cm}^{-1}\right)$ : 3408, 2980, 2935, 1727, 1599, 1497, 1456, 1375, 1303, 1250, 1154, 1108, 1055, 973, 936, 848, 821, 755, 691, 509. ${ }^{1} \mathrm{H}-\mathrm{NMR}\left(\mathrm{CDCl}_{3}, 600 \mathrm{MHz}\right) \delta(\mathrm{ppm}): 1.22(\mathrm{~d}$, $\left.6 \mathrm{H},-\mathrm{CH}\left(\mathrm{CH}_{3}\right)_{2}\right), 1.61(\mathrm{~m}, 1 \mathrm{H}$, cyclopentane $\mathrm{CH}-1), 1.67\left(\mathrm{~m}, 2 \mathrm{H}, \alpha\right.$-chain $\left.\mathrm{CH}_{2}-3\right), 1.85(\mathrm{~m}, 1 \mathrm{H}$, one of the cyclopentane $\mathrm{CH}_{2}-4$ group), 2.06 (m, 1H, one of the cyclopentane $\mathrm{CH}_{2}-4$ group), 2.09-2.16 (m, 3H, one of the $\alpha$-chain $\mathrm{CH}_{2}-4$, one of the $\alpha$-chain $\mathrm{CH}_{2}-7$ group and one of the cyclopentane $\mathrm{CH}_{2}-4$ group), 2.24-2.36 (m, 3H, $\alpha$-chain $\mathrm{CH}_{2}-2$ and one of the $\alpha$-chain $\left.\mathrm{CH}_{2}-7\right), 2.47(\mathrm{~m}, 1 \mathrm{H}$, cyclopentane $\mathrm{CH}-2), 4.02$ (m, 1H, cyclopentane CH-3), 4.17-4.22 (m, 2H, cyclopentane CH-5 and $\omega$-chain $\left.\mathrm{CH}_{2}-4\right), 5.00$ (sept, $\left.J=6.30 \mathrm{~Hz}, 1 \mathrm{H},-\mathrm{CH}\left(\mathrm{CH}_{3}\right)_{2}\right), 5.33-5.42(\mathrm{~m}, 2 \mathrm{H}, \alpha$-chain $\mathrm{CH}-5$ and $\alpha$-chain $\mathrm{CH}-6), 5.80$ (m, 1H, $\omega$-chain $\mathrm{CH}-2), 6.10$ (m, 1H, $\omega$-chain $\mathrm{CH}-1), 6.92(\mathrm{~m}, 2 \mathrm{H}$, aromatic $\mathrm{CH}-2$ and $\mathrm{CH}-6), 7.00(\mathrm{~m}, 1 \mathrm{H}$, aromatic $\mathrm{CH}-4)$, $7.30\left(\mathrm{~m}, 2 \mathrm{H}\right.$, aromatic CH-3 and CH-5). ${ }^{13} \mathrm{C}-\mathrm{NMR}\left(150 \mathrm{MHz}, \mathrm{CDCl}_{3}\right) \delta(\mathrm{ppm}): 21.8\left(2 \mathrm{~s}, 2 \mathrm{C},-\mathrm{CH}\left(\mathrm{CH}_{3}\right)_{2}\right)$, 24.8 ( $\alpha$-chain C-3), 25.7 ( $\alpha$-chain C-7), 26.6 ( $\alpha$-chain C-4), 34.0 ( $\alpha$-chain C-2), 42.9 (cyclopentane C-4), 50.5 (cyclopentane C-1), 55.7 (cyclopentane C-2), $67.7\left(-\mathrm{CH}\left(\mathrm{CH}_{3}\right)_{2}\right), 69.5\left({ }^{2} J_{\mathrm{C}-\mathrm{F}}=34.9 \mathrm{~Hz}\right.$, $\omega$-chain C-4), 73.3 (cyclopentane C-5), 77.9 (cyclopentane C-3), 114.8 (2C, aromatic C-2 and C-6), $118.2\left({ }^{1} J_{\mathrm{C}-\mathrm{F}}=240.0 \mathrm{~Hz}\right.$, $\omega$-chain C-3), 121.8 (aromatic C-4), $123.6\left({ }^{2} J_{\mathrm{C}-\mathrm{F}}=25.0 \mathrm{~Hz}, \omega\right.$-chain C-2), 128.6 ( $\alpha$-chain CH-6), 129.6 (2C, aromatic C-3 and C-5), 130.1 ( $\alpha$-chain CH-5), $138.6\left({ }^{3} J_{\mathrm{C}-\mathrm{F}}=8.8 \mathrm{~Hz}, \omega\right.$-chain C-1), 157.9 (aromatic $\mathrm{C}-1), 173.5(\mathrm{C}=\mathrm{O}) .{ }^{19} \mathrm{~F}-\mathrm{NMR}\left(470 \mathrm{MHz}, \mathrm{CDCl}_{3}\right) \delta(\mathrm{ppm}):-102.6\left({ }^{2} J_{\mathrm{F}-\mathrm{F}}=255.8 \mathrm{~Hz}\right),-103.1\left({ }^{2} J_{\mathrm{F}-\mathrm{F}}=\right.$ $255.8 \mathrm{~Hz}$ ). HRMS (ESI): calcd. for $\mathrm{C}_{25} \mathrm{H}_{34} \mathrm{O}_{5} \mathrm{NaF}_{2}[\mathrm{M}+\mathrm{Na}]^{+}$475.2272; found 475.2272.

3.6.11. (5Z)-N-Ethyl-7-\{(1R,2R,3R,5S)-2-[(1E)-3,3-difluoro-4-(phnoxy)but-1-enyl]-3,5-dihydroxycyclopentyl\}hept-5-enamide (33)

$\mathrm{EtNH}_{2}(50 \mathrm{~mL}, 629.0 \mathrm{mmol}, 70 \%$ in water $)$ was added in one portion to the tafluprost 5 (0.8 g, $1.77 \mathrm{mmol}$ ). The resulting solution was stirred for $60 \mathrm{~h}$ to disappearance of the starting material 5 (TLC, $7 \% \mathrm{MeOH} / \mathrm{CH}_{2} \mathrm{Cl}_{2}$ ). The excess of EtNH$H_{2}$ was then removed by evaporation under reduced pressure and the aqueous residue was diluted with brine $(50 \mathrm{~mL})$ and AcOEt $(50 \mathrm{~mL})$. The resulting layers were separated and the aqueous phase was extracted with AcOEt $(3 \times 25 \mathrm{~mL})$. The combined extracts were dried over anhydrous $\mathrm{Na}_{2} \mathrm{SO}_{4}$. Filtration and evaporation in vacuo furnished the crude product, which was purified by silica gel flash chromatography with gradient elution from $1 \%-5 \%$ $\mathrm{MeOH} / \mathrm{CH}_{2} \mathrm{Cl}_{2}$ to afford the title compound $33(0.66 \mathrm{~g}, 85 \%$ yield $)$ as colorless oil. $R_{\mathrm{f}}=0.34(7 \%$ $\left.\mathrm{MeOH} / \mathrm{CH}_{2} \mathrm{Cl}_{2}\right) .[\alpha]_{D}^{20}=+27.55(c 1.0, \mathrm{MeOH})$. FT-IR (thin film) $v\left(\mathrm{~cm}^{-1}\right): 3308,3095,2934,1645,1599$, 1553, 1497, 1456, 1294, 1249, 1155, 1055, 974, 933, 848, 755, 691, 509. ${ }^{1} \mathrm{H}-\mathrm{NMR}\left(\mathrm{CDCl}_{3}, 600 \mathrm{MHz}\right) \delta$ (ppm): $1.12\left(\mathrm{t}, 3 \mathrm{H},-\mathrm{CH}_{2} \mathrm{CH}_{3}\right), 1.58(\mathrm{~m}, 1 \mathrm{H}$, cyclopentane $\mathrm{CH}-1), 1.67\left(\mathrm{~m}, 2 \mathrm{H}, \alpha\right.$-chain $\left.\mathrm{CH}_{2}-3\right), 1.87(\mathrm{~m}$, $1 \mathrm{H}$, one of the cyclopentane $\mathrm{CH}_{2}-4$ group), $2.00\left(\mathrm{~m}, 1 \mathrm{H}\right.$, one of the $\alpha$-chain $\mathrm{CH}_{2}-4$ group), $2.05-2.22$ (m, $5 \mathrm{H}$, one of the $\alpha$-chain $\mathrm{CH}_{2}-4$ group, one of the $\alpha$-chain $\mathrm{CH}_{2}-7$ group, one of the cyclopentane $\mathrm{CH}_{2}-4$ group and $\alpha$-chain $\left.\mathrm{CH}_{2}-2\right), 2.38\left(\mathrm{~m}, 1 \mathrm{H}\right.$, one of the $\alpha$-chain $\mathrm{CH}_{2}-7$ group), $2.49(\mathrm{~m}, 1 \mathrm{H}$, cyclopentane CH-2), 2.94 (br s, 2H, two -OH), $3.26\left(\mathrm{~m}, 2 \mathrm{H},-\mathrm{CH}_{2} \mathrm{CH}_{3}\right), 4.04(\mathrm{~m}, 1 \mathrm{H}$, cyclopentane $\mathrm{CH}-3), 4.16-4.22$ (m, 2H, cyclopentane $\mathrm{CH}-5$ and $\omega$-chain $\left.\mathrm{CH}_{2}-4\right), 5.33-5.42(\mathrm{~m}, 2 \mathrm{H}, \alpha$-chain $\mathrm{CH}-5$ and $\alpha$-chain $\mathrm{CH}-6)$, 5.69 (br s, 1H, -Nㅍ-), 5.79 (m, 1H, $\omega$-chain CH-2), 6.11 (m, 1H, $\omega$-chain CH-1), 6.91 (m, 2H, aromatic $\mathrm{CH}-2$ and $\mathrm{CH}-6), 7.00(\mathrm{~m}, 1 \mathrm{H}$, aromatic $\mathrm{CH}-4), 7.30(\mathrm{~m}, 2 \mathrm{H}$, aromatic $\mathrm{CH}-3$ and $\mathrm{CH}-5) .{ }^{13} \mathrm{C}-\mathrm{NMR}$ $\left(150 \mathrm{MHz}, \mathrm{CDCl}_{3}\right) \delta$ (ppm): $14.8\left(-\mathrm{CH}_{2} \mathrm{CH}_{3}\right), 25.6$ ( $\alpha$-chain $\left.\mathrm{C}-3\right), 25.7$ ( $\alpha$-chain $\left.\mathrm{C}-7\right), 26.6(\alpha$-chain $\mathrm{C}-4)$, 
34.4 (- $\mathrm{CH}_{2} \mathrm{CH}_{3}$ ), 35.8 ( $\alpha$-chain $\left.\mathrm{C}-2\right), 43.1$ (cyclopentane $\mathrm{C}-4$ ), 50.7 (cyclopentane $\mathrm{C}-1$ ), 55.7 (cyclopentane C-2), $69.5\left({ }^{2} J_{\mathrm{C}-\mathrm{F}}=34.7 \mathrm{~Hz}, \omega\right.$-chain C-4), 73.1 (cyclopentane C-5), 78.0 (cyclopentane C-3), 114.8 (2C, aromatic C-2 and C-6), $118.2\left({ }^{1} J_{\mathrm{C}-\mathrm{F}}=240.0 \mathrm{~Hz}, \omega\right.$-chain C-3), 121.8 (aromatic C-4), $123.3\left({ }^{2} J_{\mathrm{C}-\mathrm{F}}=24.8 \mathrm{~Hz}\right.$, $\omega$-chain C-2), 128.9 ( $\alpha$-chain $\mathrm{CH}-6), 129.6$ (2C, aromatic C-3 and C-5), 130.0 ( $\alpha$-chain CH-5), 138.9 $\left({ }^{3} J_{\mathrm{C}-\mathrm{F}}=8.8 \mathrm{~Hz}\right.$, w-chain C-1), 158.0 (aromatic C-1), $173.2(\mathrm{C}=\mathrm{O}) .{ }^{19} \mathrm{~F}-\mathrm{NMR}\left(470 \mathrm{MHz}, \mathrm{CDCl}_{3}\right) \delta(\mathrm{ppm})$ : $-102.4\left({ }^{2} J_{\mathrm{F}-\mathrm{F}}=255.8 \mathrm{~Hz}\right),-103.1\left({ }^{2} J_{\mathrm{F}-\mathrm{F}}=255.8 \mathrm{~Hz}\right)$. HRMS (ESI): calcd. for $\mathrm{C}_{24} \mathrm{H}_{33} \mathrm{NO}_{4} \mathrm{NaF}_{2}[\mathrm{M}+\mathrm{Na}]^{+}$ 460.2275; found 460.2274 .

\section{Conclusions}

Tafluprost (5) is the newest 15-deoxy-15,15-difluorinated $\mathrm{PGF}_{2 \alpha}$ receptor agonist used as an efficacious ocular hypotensive agent in the treatment of glaucoma and ocular hypertension, and also the first hypotensive drug released in a preservative-free formulation with fewer and milder toxic effects on the eye. A novel convergent synthesis of tafluprost (5) was developed employing Julia-Lythgoe olefination of the structurally advanced phenylsulfone (5Z)-16, also successfully applied for manufacturing of pharmaceutical grade latanoprost (2), travoprost (3) and bimatoprost (4), with an aldehyde $\omega$-chain synthon 17 . The use of the same prostaglandin sulfone 16 , as a starting material in parallel syntheses of all commercially available antiglaucoma $\mathrm{PGF}_{2 \alpha}$ analogs $\mathbf{2 - 5}$, significantly reduces manufacturing costs resulting from its synthesis on an industrial scale and development of technological documentation. The preparation and identification of two other tafluprost acid (6) derivatives, tafluprost methyl ester (32) and tafluprost ethyl amide (33), are also described.

Supplementary Materials: Supplementary materials can be accessed at: http://www.mdpi.com/1420-3049/22/ $2 / 217 /$ s1.

Acknowledgments: Polish Ministry of Science and Higher Education (MNiSW) provided financial support under 3741/E-223/S/2015-2016 program. The authors would like to kindly acknowledge Anna Witkowska and Krzysztof Kuziak from the R \& D Analytical Chemistry Department, Pharmaceutical Research Institute, for recording of IR spectra and measuring optical rotations.

Author Contributions: Iwona Dams designed and carried out the synthetic experiments, analyzed the data and wrote the paper. Małgorzata Krupa, Michał Chodyński and Anna Ostaszewska participated in carrying out synthetic experiments. Piotr Cmoch carried out NMR experiments and interpreted the spectra.

Conflicts of Interest: The authors declare no conflict of interest.

\section{References}

1. Piplani, P.; Aggarwal, D.; Abbhi, V.; Saini, L. Prostaglandin analogues: Current treatment opinion for glaucoma. Med. Chem. Res. 2016, 25, 1031-1048. [CrossRef]

2. Dams, I.; Wasyluk, J.; Prost, M.; Kutner, A. Therapeutic uses of prostaglandin $F_{2 \alpha}$ analogues in ocular disease and novel synthetic strategies. Prostaglandins. Other Lipid Med. 2013, 104-105, 109-121. [CrossRef] [PubMed]

3. Fung, D.S.; Whitson, J.T. An evidence-based review of unoprostone isopropyl ophthalmic solution $0.15 \%$ for glaucoma: Place in therapy. Clin. Ophthalmol. 2014, 8, 543-554. [PubMed]

4. Perry, C.M.; McGavin, J.K.; Culy, C.R.; Ibbotson, T. Latanoprost: An update of its use in glaucoma and ocular hypertension. Drugs Aging 2003, 20, 597-630. [CrossRef] [PubMed]

5. Waugh, J.; Jarvis, B. Travoprost. Drugs Aging 2002, 19, 465-471. [CrossRef] [PubMed]

6. Easthope, S.E.; Perry, C.M. Topical bimatoprost: A review of its use in open-angle glaucoma and ocular hypertension. Drugs Aging 2002, 19, 231-248. [CrossRef] [PubMed]

7. Hommer, A. A review of preserved and preservative-free prostaglandin analogues for the treatment of open-angle glaucoma and ocular hypertension. Drugs Today 2010, 46, 409-416. [CrossRef] [PubMed]

8. Wang, Y.; Bolós, J.; Serradell, N. Tafluprost. Drugs Future 2006, 31, 788-792. [CrossRef]

9. Matsumura, Y.; Mori, N.; Nakano, T.; Sasakura, H.; Matsugi, T.; Hara, H.; Morizawa, Y. Synthesis of the highly potent prostanoid FP receptor agonist, AFP-168: A novel 15-deoxy-15,15-difluoroprostaglandin $\mathrm{F}_{2 \alpha}$ derivative. Tetrahedron Lett. 2004, 45, 1527-1529. [CrossRef]

10. Pozarowska, D. Safety and tolerability of tafluprost in treatment of elevated intraocular pressure in open-angle glaucoma and ocular hypertension. Clin. Ophthalmol. 2010, 4, 1229-1236. [CrossRef] [PubMed] 
11. Swymer, C.; Neville, M.W. Tafluprost: The first preservative-free prostaglandin to treat open-angle glaucoma and ocular hypertension. Ann. Pharmacother. 2012, 46, 1506-1510. [CrossRef] [PubMed]

12. Konstas, A.G.P.; Quaranta, L.; Katsanos, A.; Riva, I.; Tsai, J.C.; Giannopoulos, T.; Voudouragkaki, I.C.; Paschalinou, E.; Floriani, I.; Haidich, A.-B. Twenty-four hour efficacy with preservative free tafluprost compared with latanoprost in patients with primary open angle glaucoma or ocular hypertension. Br. J. Ophthalmol. 2013, 97, 1510-1515. [CrossRef] [PubMed]

13. Takagi, Y.; Nakajima, T.; Shimazaki, A.; Kageyama, M.; Matsugi, T.; Matsumura, Y.; Gabelt, B.-T.; Kaufaman, P.L.; Hara, H. Pharmacological characteristics of AFP-168 (tafluprost), a new prostanoid FP receptor agonist, as an ocular hypotensive drug. Exp. Eye Res. 2004, 78, 767-776. [CrossRef] [PubMed]

14. Merck Sharpe \& Dohme Ltd. SAFLUTAN 15 Micrograms/ml, Eye Drops, Solution, in Single-Dose Container: UK Summary of Product Characteristics. 2014. Available online: http://www.mhra.gov.uk/spc-pil/ (accessed on 22 November 2016).

15. Corey, E.J.; Weinshenker, N.M.; Schaaf, T.K.; Huber, W.J. Stereo-controlled synthesis of prostaglandins $F_{2 \alpha}$ and $\mathrm{E}_{2}$ (dl). J. Am. Chem. Soc. 1969, 91, 5675-5677. [CrossRef] [PubMed]

16. Corey, E.J.; Schaaf, T.K.; Huber, W.; Koelliker, U.; Weinshenker, N.M. Total synthesis of prostaglandins $F_{2 \alpha}$ and $\mathrm{E}_{2}$ as the naturally occurring forms. J. Am. Chem. Soc. 1970, 92, 397-398. [CrossRef] [PubMed]

17. Corey, E.J.; Noyori, R.; Schaaf, T.K. Total synthesis of prostaglandins $F_{1 \alpha}, E_{1}$, and $E_{2}$ (natural forms) from a common synthetic intermediate. J. Am. Chem. Soc. 1970, 92, 2586-2587. [CrossRef] [PubMed]

18. Corey, E.J. The logic of chemical synthesis: Multistep synthesis of complex carbogenic molecules (Nobel lecture). Angew. Chem. Int. Ed. Engl. 1991, 30, 455-465. [CrossRef]

19. Resul, B.; Stjernschantz, J.; No, K.; Liljebris, C.; Selén, G.; Astin, M.; Karlsson, M.; Bito, L.Z. Phenyl-substituted prostaglandins: Potent and selective antiglaucoma agents. J. Med. Chem. 1993, 36, 243-248. [CrossRef] [PubMed]

20. Selliah, R.; Dantanarayana, A.; Haggard, K.; Egan, J.; Do, E.U.; May, J.A. Synthesis of [phenyl-2-3H]-travoprost: Isopropyl ester prodrug of a selective prostaglandin FP receptor agonist. J. Label. Compd. Radiopharm. 2001, 44, 173-183. [CrossRef]

21. Collins, P.W.; Djuric, S.W. Synthesis of therapeutically useful prostaglandin and prostacyclin analogs. Chem. Rev. 1993, 93, 1533-1564. [CrossRef]

22. Liljebris, C.; Selén, G.; Resul, B.; Stjernschantz, J.; Hacksell, U. Derivatives of 17-phenyl-18,19,20trinorprostaglandin $\mathrm{F}_{2 \alpha}$ isopropyl ester: Potential antiglaucoma agents. J. Med. Chem. 1995, 38, 289-304. [CrossRef] [PubMed]

23. Bowler, J.; Crossley, N.S. Cyclopentane Derivatives. GB Patent 1,350,971, 24 April 1974.

24. Gutman, A.; Nisnevich, G.; Etinger, M.; Zaltzman, I.; Yudovich, L.; Pertsikov, B.; Tishin, B. Process for the Preparation of Prostaglandin Derivatives. U.S. Patent 2005/0209337 A1, 8 September 2005.

25. Woodward, D.F.; Andres, S.W.; Burk, R.M.; Garst, M.E. Non-Acidic Cyclopentane Heptanoic Acid, 2-Cycloalkyl or Arylalkyl Derivatives as Therapeutic Agents. WO 94/06433, 31 March 1994.

26. Henegar, K.E. Process and Intermediates to Prepare Latanoprost. US Patent 2003/0187071 A1, 2 February 2003.

27. Martynow, J.G.; Jóźwik, J.; Szelejewski, W.; Achmatowicz, O.; Kutner, A.; Wiśniewski, K.; Winiarski, J.; Zegrocka-Stendel, O.; Gołębiewski, P. A new synthetic approach to high-purity (15R)-latanoprost. Eur. J. Org. Chem. 2007, 4, 689-703. [CrossRef]

28. Dams, I.; Chodyński, M.; Krupa, M.; Pietraszek, A.; Zezula, M.; Cmoch, P.; Kosińska, M.; Kutner, A. A novel convergent synthesis of the potent antiglaucoma agent travoprost. Tetrahedron 2013, 69, 1634-1648. [CrossRef]

29. Dams, I.; Chodyński, M.; Krupa, M.; Pietraszek, A.; Zezula, M.; Cmoch, P.; Kosińska, M.; Kutner, A. A novel convergent synthesis of the antiglaucoma $\mathrm{PGF}_{2 \alpha}$ analogue bimatoprost. Chirality 2013, 25, 170-179. [CrossRef] [PubMed]

30. Quigley, H.A.; Broman, A.T. The number of people with glaucoma worldwide in 2010 and 2020. Br. J. Ophthalmol. 2006, 90, 262-267. [CrossRef] [PubMed]

31. Marchei, E.; de Orsi, D.; Guarino, C.; Rotolo, M.C.; Graziano, S.; Pichini, S. High performance liquid chromatography tandem mass spectrometry measurement of bimatoprost, latnaoprost and travoprost in eyelash enhancing cosmetic serums. Cosmetics 2016, 3, 4. [CrossRef]

32. Nakajima, T.; Matsugi, T.; Goto, W.; Kageyama, M.; Mori, N.; Matsumura, Y.; Hara, H. New fluoroprostaglandin $\mathrm{F}_{2} \alpha$ derivatives with prostanoid FP-receptor agonistic activity as potent ocular-hypotensive agents. Biol. Pharm. Bull. 2003, 26, 1691-1695. [CrossRef] [PubMed] 
33. Shirasawa, E.; Kageyama, M.; Nakajima, T.; Nakano, T.; Mori, N.; Sasakura, H.; Matsumura, Y.; Morizawa, Y. Difluoroprostaglandin Derivatives and Their Use. EP Patent 0850926 A2, 1 July 1998.

34. Brinkenhoff, M.C. Composition, Metod and Kit for Enhancing Hair. US Patent 2011/0293549 A1, 1 December 2011.

35. Julia, M.; Paris, J.-M. Syntheses a l'aide de sulfones $\mathrm{V}^{(+)}$-Methode de synthese generale de doubles liaisone. Tetrahedron Lett. 1973, 14, 4833-4836. [CrossRef]

36. Kocieński, P.J.; Lythgoe, B.; Ruston, S. Scope and stereochemistry of an olefin synthesis from $\beta$-hydroxysulphones. J. Chem. Soc. Perkin Trans. 1978, 1, 829-834. [CrossRef]

37. Kocieński, P.J. Recent sulphone-based olefination reactions. Phosphorus Sulphur Relat. Elem. 1985, 24, 97-127. [CrossRef]

38. For synthesis of (S)-26 and (R)-18 enantiomers see: Lin, P.; Chang, L.; Edmondson, S.D. Pyrrolidine-Derived beta 3 Adrenergic Receptor Agonists. WO Patent 2010/129326 A1, 11 November 2010.

39. Trost, B.M.; Arndt, H.C.; Strege, P.E.; Verhoeven, T.R. Desulfonylation of aryl alkyl sulfones. Tetrahedron Lett. 1976, 17, 3477-3478. [CrossRef]

40. Blakemore, P.R.; Ho, D.K.H.; Nap, W.M. Ethyl (benzothiol-2-ylsulfonyl)acetate: A new reagent for the stereoselective synthesis of $\alpha, \beta$-unsaturated esters from aldehydes. Org. Biomol. Chem. 2005, 3, 1365-1368. [CrossRef] [PubMed]

41. Dess, D.B.; Martin, J.C. Readily accessible 12-I-5 ${ }^{1}$ oxidant for the conversion of primary and secondary alcohols to aldehydes and ketones. J. Org. Chem. 1983, 48, 4155-4156. [CrossRef]

42. Beaulieu, F.; Beauregard, L.-P.; Courchesne, G.; Couturier, M.; LaFlamme, F.; L'Heureux, A. Aminodifluorosulfinium tetrafluoroborate salts as stable and crystalline deoxofluorinating reagents. Org. Lett. 2009, 11, 5050-5053. [CrossRef] [PubMed]

43. L'Heureux, A.; Beaulieu, F.; Bennett, C.; Bill, D.R.; Clayton, S.; LaFlamme, F.; Mirmehrabi, M.; Tadayon, S.; Tovell, D.; Couturier, M. Aminodifluorosulfinium salts: Selective fluorination reagents with enhanced thermal stability and ease of handling. J. Org. Chem. 2010, 75, 3401-3411. [CrossRef] [PubMed]

44. Tellier, F.; Sauvêtre, R. Introduction stéréosélective du groupment difluorométhylène en position allylique. J. Fluorine Chem. 1995, 70, 265-270. [CrossRef]

45. Wu, P.; Wu, H.; Wen, W. Metal-Catalyzed Asymmetric 1,4-Conjugate Addition of Vinylboron Compounds to 2-Substituted-4-Oxy-Cyclopent-2-en-1-Ones Yielding Prostaglandins and Prostaglandin Analogs. WO Patent 2016/005943 A1, 14 January 2016.

Sample Availability: Samples of the compounds 5-6, 17, 20-25 and 27-33 and are available from the authors.

(C) 2017 by the authors; licensee MDPI, Basel, Switzerland. This article is an open access article distributed under the terms and conditions of the Creative Commons Attribution (CC BY) license (http:/ / creativecommons.org/licenses/by/4.0/). 